\title{
Formulation and characterization of etoricoxib solid dispersion using natural polymers
}

\section{Doğal polimerleri kullanarak etoricoxib katı dispersiyonunun formülasyonu ve karakterizasyonu}

\begin{abstract}
Sandip Babarao Sapkal, Vaibhav Suresh Adhao, Raju Rambhau Thenge, Rahul Ashok Darakhe, Sushilkumar Ananda Shinde, Vinayak Natthuji Shrikhande Department of Pharmaceutics, Dr. Rajendra Gode College of Pharmacy, Malkapur443101, Dist. Buldana, Maharashtra
\end{abstract}

\section{ABSTRACT}

Objective: The main objective of the present investigation to develop and evaluate solid dispersions of BCS Class II drugs Etoricoxib employing various natural polymers, compatible with conventional manufacturing method to enhance solubility of poorly soluble drugs.

Materials and Methods: In this study, etoricoxib solid dispersion was prepared using xanthan gum, guar gum and gum acacia and their combinations by solvent evaporation method. Solid dispersions and pure etoricoxib in the form of powder were characterized in comparison with pure drug and corresponding physical mixtures in the same ratios by Fourier transform infrared spectroscopy (FTIR), differential scanning calorimetry (DSC), powder x-ray diffractogram (XRPD), and in vitro drug release.

Results: Solid dispersion (ET11) prepared with 1:2:2:2 drug carrier ratios were showed highest solubility in different solvents. Hence the solid dispersion (ET11) of 1:2:2:2 ratios were selected for characterization. The DSC study indicated that the crystalline nature of Etoricoxib was reduced to amorphous. The diffraction pattern of the solid dispersions in each figure indicates that diffraction peaks at $2 \theta$ values has less intensity than that of pure drugs. This indicated that the crystalline nature of drug sample was converted to amorphous with solid dispersion (ET11). SEM photographs of solid dispersion seem to be more porous in nature. From the in- vitro drug release profile, it can be seen that formulation ETM11 shows higher dissolution rate i.e. $98.2 \pm 1.3 \%$ 
compared with other formulations. It is predicted that, increasing concentration of carrier, increases the drug dissolution rate.

Conclusion: This study has shown that the solid dispersion of etoricoxib using natural carrier can be promising formulation for solubility and dissolution enhancement. Natural polymers used have shown promising results in the modification of drug release from the formulations.

Key words: Etoricoxib, solid dispersions, Xanthan gum, guar gum, gum acacia

\section{soyut}

Amaç: Bu araştırmanın temel amacı, zayıf çözünür ilaçların çözünürlügünü arttırmak için geleneksel üretim yöntemiyle uyumlu çeşitli doğal polimerler kullanan BCS Sınıf II ilaç Etoricoxib katı dispersiyonlarının geliştirilmesi ve değerlendirilmesidir.

Gereç ve Yöntem: Bu çalışmada ksantan sakızı, guar zamkı ve akasya ve bunların kombinasyonları çözücü buharlaştırma yöntemi ile etoricoxib katı dispersiyonu hazırlandı. Toz halinde katı dispersiyonlar ve saf etoricoksib, saf ilaç ve karşılık gelen fiziksel karışımların Fourier dönüşümü kızıötesi spektroskopisi (FTIR), diferansiyel tarama kalorimetrisi (DSC), toz $\mathrm{x}$-ş̧ını difraktogramı (XRPD) ile aynı oranlarda karşılaştırıması ile karakterize ediidi. ve in vitro ilaç salımı.

Sonuçlar: 1: 2: 2: 2 ilaç taşıyıcı oranları ile hazırlanan katı dispersiyon (ET11), farklı çözücüler içinde en yüksek çözünüriük göstermiştir. Bu nedenle 1: 2: 2: 2 oranındaki katı dispersiyon (ET11) karakterizasyonu için seçilmiştir. DSC çalışması, Etoricoxib'in kristalin yapısının amorfuma indirildiğini gösterdi. Her bir şekildeki katı dispersiyonların kırınım modeli, $2 \theta$ değerlerinde kırınım doruklarının, saf ilaçlardan daha az yoğunluğa sahip olduğunu göstermektedir. Bu, ilaç numunesinin kristalin yapısının, katı dispersiyon (ET11) iie şekilsiz hale getirildiğini gösterdi. Katı dispersiyonun SEM fotoğrafları doğada daha gözenekli görünmektedir. İn vitro ilaç salım profilinden, ETM11 formülasyonunun diğer formülasyonlarla karşılaştıııldığında daha yüksek çözünme oranı yani\% $98.2 \pm 1.3$ gösterdiğini görülebilir. Taşıyıcının artan konsantrasyonunun, ilaç çözünme oranını arttırdığı tahmin edilmektedir.

Sonuç: Bu çalışma, etoricoxib'in doğal taşıyıcı kullanılarak katı dispersiyonunun, çözünürlük ve çözünme artırımı için ümit verici bir formülasyon olabileceğini 
göstermiştir. Kullanılan doğal polimerler, formülasyonlardan ilaç salımının modifikasyonunda ümit verici sonuçlar vermiştir.

Anahtar kelimeler: Etoricoxib, katı dispersiyonlar, Ksantan sakızı, guar sakızı, sakız akasyası

\section{INTRODUCTION}

Poorly water-soluble drugs are expected to have dissolution-limited absorption. Increasing the drug solubility may substantially contribute to improved drug absorption, and consequently, drug bioavailability. There are several pharmaceutical strategies available to improve the aqueous solubility of poorly soluble drugs: solid dispersion, solubilization using surfactants, the use of cosolvents, and reduction of particle size, hydrotrophy and the use of aqueous soluble derivative or salts. 1,2 Solid dispersion techniques have been used to enhance the dissolution and oral bioavailability of many poorly soluble drugs. ${ }^{3}$ One aspect of solid dispersion technology on which most workers in the field would agree is that the number of marketed products arising from this approach has been disappointing. Indeed, the sheer simplicity of the manufacturing method, the fact that in general only the drug and carrier are required and the frequently reported improvements in both the dissolution rate and bioavailability would lead one to expect that the transfer to the market place would be rapid and widespread. Research for alternative carriers has been increasing to suit for the industrial applications as well as to reduce the production cost and toxic effects. Recently, many natural polymers have been evaluated for their use in new applications. The dissolution rate of drugs from the formulations containing viscous carriers is generally low due to the formation of gel layer on the hydrated surfaces, which prevents the drug release during dissolution. This can be overcome during tablet formulation by adding disintegrants. Pulverization of the product is also another important draw back with the high viscosity carriers, which can be overcome by using decreasing order of polymer/drug ratio during formulation. ${ }^{4,5}$ The poor aqueous solubility and wettability of etoricoxib, 5-chloro-6-methyl-3 [4-(methyl sulfonyl)phenyl]-2, 3-bypyridine, is a highly selective second generation cyclooxygenage-2 (COX-2) inhibitor, administered orally as an analgesic and nonsteroidal anti-inflammatory drug (NSAID), cause difficulties in the formulation of oral dosage forms and lead to variable bioavailability. ${ }^{6}$ It is used in the treatment of 
rheumatoid arthritis, osteoarthritis, postoperative dental pain, chronic back pain, and acute gout. Moreover, recent studies evidenced its efficacy in patients with ankylosing spondylitis. But it's very low aqueous solubility and poor dissolution can cause formulation problems and limit its therapeutic application by delaying the rate of absorption and the onset of action..$^{7-10}$ Hence, enhancement of solubility and/or dissolution rate of etoricoxib can be achieved by preparation of solid dispersions. Miany authors formulated solid dispersions of etoricoxib using number of various polymers and methods. Still less attempts has been made to prepare solid dispersion of etoricoxib using natural polymers like xanthan gum, Guar gum and gum acacia as carriers for solid dispersion of etoricoxib to improve the aqueous solubility and dissolution enhancement of etoricoxib.

In the present study, a solvent evaporation technique has been used to prepare solid dispersions with natural carriers, mainly xanthan gum, Guar gum and gum acacia and their combinations. Solid dispersions and pure etoricoxib in the form of powder were characterized in comparison with pure drug and corresponding physical mixtures in the same ratios by Fourier transform infrared spectroscopy (FTIR), differential scanning calorimetry (DSC), powder x-ray diffractogram (XRPD), and in vitro drug release.

\section{MATERIALS AND METHOD}

Etoricoxib pure drug was gift sample from Abbott Health Care Pvt Ltd, Mumbai India. Xanthan gum, Guar gum and Gum Acacia were obtained from SD fine chemicals, Mumbai. All other chemicals used were of analytical grade.

\section{Ultraviolet-Visible Absorption Spectroscopy ${ }^{11}$}

UV Spectrophotometer from Shimadzu CORP. UV-1800 was used for all UV-Visible spectroscopic studies. For the quantitative determination of the drug in various samples, the Beer-Lambert's Law was used. The first step was to create a standard calibration curve. To prepare a calibration curve the drug was dissolved in of a suitable solvent. An aliquot was withdrawn from this and diluted. Various concentrations were made by serial dilution of this basic stock solution. The various solutions were measured, in triplicate, using UV-Visible absorption spectroscopy to get absorption data. The data, 
which was a mean of the three readings obtained, was used to prepare a calibration curve. This curve was further used for the determination of the concentration of the drug in any formulation or during the dissolution studies.

\section{Development of calibration curve for Etoricoxib}

The stock solution of Etoricoxib was accordingly diluted to obtain concentration range of $0-10 \mu \mathrm{g} / \mathrm{ml}$. The absorbance was observed against methanol as blank and th calibration curve was plotted between concentration ( $x$ axis) and absorbance ( $y$ axis)

\section{Partition Coefficient Determination of Drug}

Partition coefficient (oil/water) is a measure of a drug's lipophilicity and an indication of its ability to cross cell membranes. It is defined as the ratio of un-ionized drug distributed between the organic and aqueous phases at equilibrium.

$$
\mathrm{Po} / \mathrm{w}=\left(\mathrm{C}_{\text {oil }} / \mathrm{C}_{\text {water }}\right) \text { equilib rium }
$$

The partition coefficient is commonly determined using an oil phase of octanol or chloroform and water. Drugs having values of $P$ much greater than 1 are classified as lipophilic, where as those with partition coefficients much less than 1 are indicative of a hydrophilic drug. Before partition coefficient was determined, the phases of the solvent system were mutually saturated by shaking at the temperature of the experiment by Shake Flask method for $\mathrm{Po} / \mathrm{w}$. In which, accurately weighed sample of Etoricoxib (10 mg each) was taken in a conical flask containing pre-saturated mixture of known quantity of high purity analytical grade n-octanol and double distilled water in 1:1 v/v ratio (25ml: $25 \mathrm{ml}$ ); which were then shaken for 100 rotations in five minutes and allowed to stand long enough again to allow the phases to separate. Afterwards aqueous phase was sampled by a procedure that minimizes the risk of including traces of n-octanol by syringe. The quantity of substance present in n-octanol phase was calculated by subtracting the quantity of substance in aqueous phase from the quantity of the substance originally introduced. Finally, Partition coefficient was calculated using equation. The same procedure was performed thrice and average of Po/w was calculated. 


\section{Solubility Determination and Phase Solubility Study}

The solubility of Etoricoxib was determined by the equilibrium solubility method in which a saturated solution of the material was obtained by stirring an excess of drug in the constant quantity of solvent until saturation or equilibrium was achieved in vortex mixer. Then it was filtered through whatmann filter paper (No.1) and then concentration was analyzed by UV spectrophotometer at $284 \mathrm{~nm}$. Solubility of etoricoxib was determined in distilled water and $\mathrm{pH}$ across the GIT. i.e. in $\mathrm{pH} \mathrm{1.2,} 4.5$ and $\mathrm{pH}$ 6.8. Phase solubility studies of etoricoxib was carried out to evaluate the possible solubilizing effect of the carrier by adding an excess of drug to $10 \mathrm{ml}$ of aqueous solutions containing increasing concentrations of Gum Acacia, Guar gum and Xanthan gum (0-2\% w/v) and shaken at $25^{\circ} \mathrm{C}$ in a temperature controlled bath for $72 \mathrm{hrs}$. Drug concentrations were assessed spectrophotometrically. ${ }^{12}$

\section{Preparation of solid dispersions and physical mixtures}

Etoricoxib solid dispersions were prepared using Xanthan gum, Guar gum and Gum Acacia by the solvent evaporation method. A $1 \mathrm{~g}$ quantity of etoricoxib and natural carrier were dissolved separately in $100 \mathrm{ml}$ of absolute ethanol. The solution was stirred for $1 \mathrm{~h}$ and the solvent was allowed to evaporate at room temperature. The solid dispersions obtained (ET1) were pulverized sieved through 22 meshes and then stored in screw cap vials at room temperature pending further use. The same procedure was carried out for all the formulations presented in Table 1.

Physical mixtures of the etoricoxib and carriers, having the same composition of the solid dispersions were prepared (ETM1) by simply triturating the drugs and the polymers in a porcelain mortar. ${ }^{13}$ The mixtures were sieved and stored in screw cap vials at room temperature pending further use. The same procedure was carried out for all the formulations presented in Table 2.

Table 1: Composition of etoricoxib solid dispersions

\begin{tabular}{|l|l|l|}
\hline Formulation & $\begin{array}{l}\text { Formulation } \\
\text { code }\end{array}$ & $\begin{array}{l}\text { Etoricoxib: Xanthan gum: Guar gum: Gum } \\
\text { Acacia ratios }\end{array}$ \\
\hline & ET1 & $1: 1: 0: 0$ \\
\hline
\end{tabular}




\begin{tabular}{|l|l|l|}
\hline \multirow{5}{*}{ Solid dispersion } & ET2 & $1: 2: 0: 0$ \\
\cline { 2 - 3 } & ET3 & $1: 0: 1: 0$ \\
\cline { 2 - 3 } & ET4 & $1: 0: 2: 0$ \\
\cline { 2 - 3 } & ET5 & $1: 0: 0: 1$ \\
\cline { 2 - 3 } & ET6 & $1: 0: 0: 2$ \\
\cline { 2 - 3 } & ET7 & $1: 1: 1: 1$ \\
\cline { 2 - 3 } & ET8 & $1: 2: 1: 1$ \\
\cline { 2 - 3 } & ET9 & $1: 1: 2: 1$ \\
\hline & ET10 & $1: 1: 1: 2$ \\
\cline { 2 - 3 } & ET11 & $1: 2: 2: 2$ \\
\hline
\end{tabular}

Table 2: Composition of etoricoxib physical mixture

\begin{tabular}{|c|c|c|}
\hline Formulation & $\begin{array}{l}\text { Formulation } \\
\text { code }\end{array}$ & $\begin{array}{l}\text { Etoricoxib: Xanthan gum: Guar gum: Gum } \\
\text { Acacia ratios }\end{array}$ \\
\hline \multirow{11}{*}{$\begin{array}{l}\text { Physical } \\
\text { mixture }\end{array}$} & ETM1 & $1: 1: 0: 0$ \\
\hline & ETM2 & $1: 2: 0: 0$ \\
\hline & ETM3 & $1: 0: 1: 0$ \\
\hline & ETM4 & $1: 0: 2: 0$ \\
\hline & ETM5 & $1: 0: 0: 1$ \\
\hline & ETM 6 & 1:0:0:2 \\
\hline & ETM & 1:1:1:1 \\
\hline & ETM8 & $1: 2: 1: 1$ \\
\hline & ET M9 & $1: 1: 2: 1$ \\
\hline & ETM10 & $1: 1: 1: 2$ \\
\hline & ETM11 & $1: 2: 2: 2$ \\
\hline
\end{tabular}

Determination of solubility of various solid dispersions

Etoricoxib loaded-solid dispersions, physical mixtures and pure Etoricoxib equivalent to $30 \mathrm{mg}$ were weighed and transferred to four flask containing $50 \mathrm{ml}$ distilled water, $\mathrm{pH}$ 1.2 acetate buffer, Phosphate buffer $\mathrm{pH} 6.8$ and Phosphate buffer $\mathrm{pH} 7.4$. The sample 
was agitated at $80 \mathrm{rpm}$ in thermostated shaking water bath at $37 \pm 0.5^{\circ} \mathrm{C}$ for $8 \mathrm{hrs}$. The supernant solution was then filtered through a Whatmann filter paper. The filtrate was diluted and the absorbance was measured using UV-Vis spectrophotometer. ${ }^{12}$

\section{Determination of percent yield}

The percent yield of Etoricoxib solid dispersions was determined according to method described using the following expression

$$
\begin{gathered}
\% \text { yield }=\frac{\text { weight of prepared SD }}{} \times 100 \\
\text { Wt. of drug }+ \text { carrier }
\end{gathered}
$$

Eq.

\section{Estimation of drug content of Solid dispersion and Physical mixture}

Solid dispersions equivalent to $60 \mathrm{mg}$ of etoricoxib were weighed accurately and dissolved in a suitable quantity of methanol. The solutions were filtered through a membrane filter $(0.45 \mathrm{~mm})$. The drug content was determined at $284 \mathrm{~nm}$ by UV spectrophotometer after suitable dilution. ${ }^{14}$

\section{Dissolution studies}

The dissolution studies were performed using a US Pharmacopeia 24 type II dissolution test apparatus. The samples equivalent to $60 \mathrm{mg}$ etoricoxib were placed in a dissolution vessel containing $900 \mathrm{~mL}$ of phosphate buffer ( $\mathrm{pH} \mathrm{6.8)} \mathrm{maintained} \mathrm{at} 37^{\circ} \mathrm{C}$ and stirred at $100 \mathrm{rpm}$. Samples were collected periodically and replaced with a fresh dissolution medium. After filtration through Whatman filter paper no. 41, a concentration of etoricoxib was determined spectrophotometrically at $284 \mathrm{~nm}$. Dissolution studies were performed in triplicate $(n=3)$, the calculated mean values of cumulative drug release were used while plotting the release curves.

\section{Fourier Transform Infra-Red (FT-IR) studies}

Compatibility studies of each drug (Etoricoxib) with Xanthan gum, Guar gum, and Gum Acacia were carried out using Fourier Transform Infrared (FT-IR) spectroscopy. Sample from each of drug alone, carrier alone and physical mixture of drug and polymer by ATR 
sampling technique, the spectrum was scanned over the frequency range between 4000 and $600 \mathrm{~cm}^{-1}$ and at $4 \mathrm{~cm}$ resolution. Appearance, disappearance or broadening of absorption band(s) on the spectra of the solid dispersions and the polymeric carriers in comparison with the spectrum of drug were used to determine possible interactions between pure drugs and polymers.

\section{Differential Scanning Calorimetry}

A Mettler Toledo DSC STAR ${ }^{\text {e }}$ SYSTEM was used for all the DSC studies performed on the Drug, polymer, physical mixtures and solid dispersions. The DSC uses Stare Software V8.10 for its operation. Samples ranging from 8 to $15 \mathrm{mg}$ were used and the results were normalized using Stare software so that the results could be compared. The samples were placed in a $100 \mu \mathrm{L}$ pan. The pans are covered with a lid and the lid is crimped into place. A pinhole is made on the lid to vent out any gas which might result while heating. The pan is then placed inside the furnace using an empty pan as a blank. The DSC was calibrated using indium (5-10 $\mathrm{mg})$ with a melting onset temperature at $156 \pm 0.2^{\circ} \mathrm{C}$ and zinc with a melting onset temperature of $419.6 \pm 0.7^{\circ} \mathrm{C}$ as the standards. The two processes show a heat flow of $28.45 \pm 0.6 \mathrm{~J} / \mathrm{g}$ and $107.5 \pm 3.2 \mathrm{~J} / \mathrm{g}$ for indium and zinc, respectively.

\section{Powder X-Ray Diffraction (PXRD)}

PXRD studies were performed to check for any crystallinity in the formulation after it was made and after the stability studies were performed. Avoiding recrystallization of the drug in the formulation was one of the goals of this study. PAN analytical X-Pert Pro V1.6 with X Pert Data Collector V2.1 software was used equipped with a CuKa2 anode tube and diffractometer of radius $240 \mathrm{~mm}$. The XRD scan was performed using BB004 flat stage. The powdered sample was placed in an aluminum sample holder which had a one-inch square with a depth of $0.5 \mathrm{~mm}$. Data were collected by scanning the sample at $45 \mathrm{kV}$ and $40 \mathrm{~mA}$. Samples were scanned from $5-50^{\circ} \mathrm{C} 2 \theta$ at a step size of 0.0170 and scan rate of $1.0^{\circ} \mathrm{C} / \mathrm{min}$.

\section{Scanning Electron Microscopy (SEM)}

Surface morphology of the raw materials and the formulated product were studied using a Scanning electron microscope equipped with JOEL JSM 7500. Snappy 4 software was used to obtain the digital picture. Samples were placed on brass stubs using 
double sided adhesive tape. The samples were coated with a layer of gold using a gold sputter technique to improve the conductivity of the surface of the sample to obtain good images. A Denton Vacuum Desk II was used for the gold sputter technique. Pictures were taken at magnifications whereby they could be compared with each other, which best shows the surface features of the various materials.

\section{RESULT \& DISCUSSION}

\section{Preformulation studies of etoricoxib}

The standard drug absorbance in methanol with range 0 to $10 \mu \mathrm{g} / \mathrm{ml}$ concentration at $284 \mathrm{~nm}$ is reported in table 3. Standard curve obeyed Beers lamberts law in the range of 0 to $10 \mu \mathrm{g} / \mathrm{ml}$. Data in this range was subjected to linear regression analysis. The graphical presentation of linear curve of Etoricoxib in methanol is shown in figure 1 and found linear.

Table 3: standard absorbance of Etoricoxib in methanol

Correlation coeficient $\left(R^{2}\right)=0.999$

\begin{tabular}{|c|c|}
\hline $\begin{array}{l}\text { conc. of drug } \\
(\boldsymbol{\mu g} / \mathrm{ml})\end{array}$ & $\begin{array}{l}\text { Absorbance at 284 } \\
\mathbf{n m}\end{array}$ \\
\hline 0 & 0 \\
\hline 2 & 0.18 \\
\hline 4 & 0.321 \\
\hline 6 & 0.494 \\
\hline 8 & 0.655 \\
\hline 10 & 0.793 \\
\hline
\end{tabular}

Equation of regressed line; $Y=0.0071 x+0.023$

\section{Where,}

$X=$ value of concentration,

$\mathrm{Y}=$ Regressed value of absorbance 


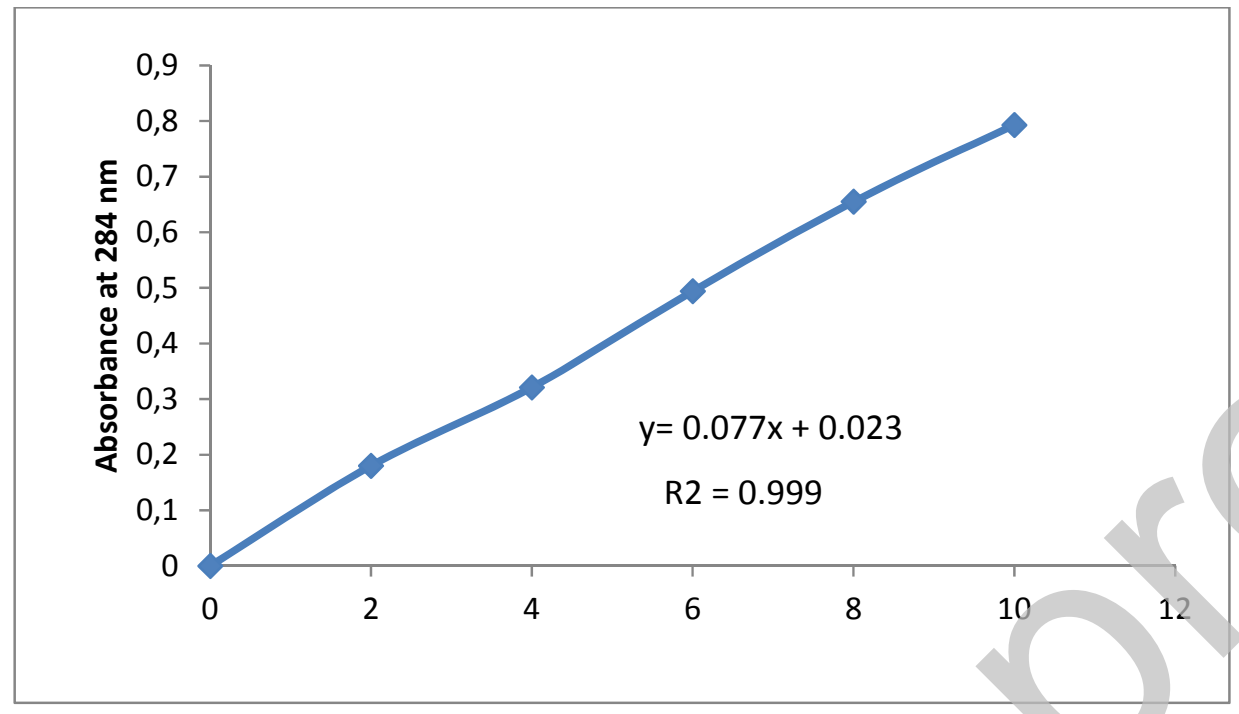

Figure 1: Standard calibration curve of Etoricoxib

In the preformulation study of drug, $\lambda$-max of Etoricoxib was found at $284 \mathrm{~nm}$. Similarly Partition coefficient of Etoricoxib was found to be 3.9 by shake flask method, which indicates that Etoricoxib is lipophilic. So it can pass cell membrane easily once it got solubilized.

\section{Saturation solubility and phase solubility}

The solubility data of etoricoxib in distilled water, Acetate buffer $\mathrm{pH} 1.2$, Phosphate buffer $\mathrm{pH} 6.8$ and Phosphate buffer $\mathrm{pH} 7.4$ at $25^{\circ} \mathrm{C}$ are depicted in table 4 . The comparative statement of etoricoxib in different solvent is presented graphically in figure 2.

Table 4: Solubility data of Etoricoxib in different solvent

\begin{tabular}{|c|c|}
\hline Solubility solvents & Concentration $(\boldsymbol{\mu g} / \mathbf{m l})$ \\
\hline Water & 24.49 \\
\hline Acetate buffer $\mathrm{pH} \mathrm{1.2}$ & 10.25 \\
\hline Phosphate buffer $\mathrm{pH} 6.8$ & 77.16 \\
\hline Phosphate buffer $\mathrm{pH} \mathrm{7.4}$ & 78.48 \\
\hline
\end{tabular}




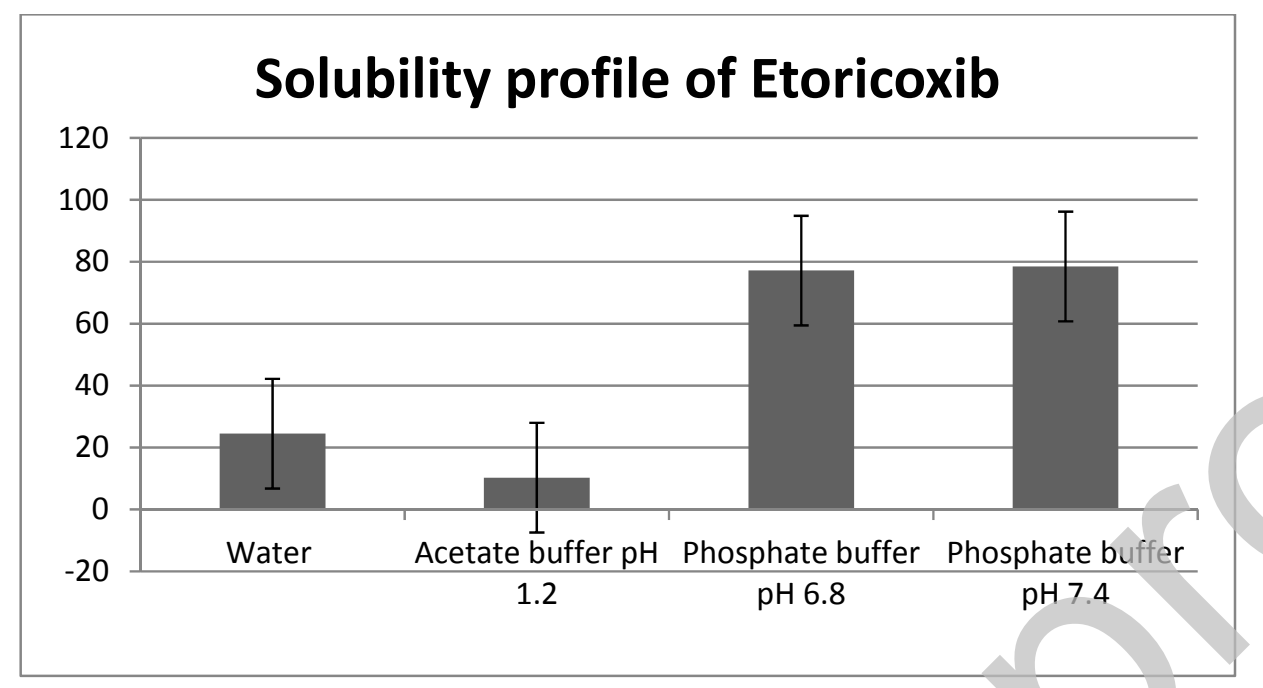

Figure 2: Solubility profile of etoricoxib

Phase solubility curve of etoricoxib in presence of natural carriers viz; Xanthan gum, guar gum and Gum Acacia is shown in figure no. 3. A systematic increase of solubility of drugs was observed with an increasing concentration of natural polymers in water. Increased solubility may be due to improved dissolution of drugs in water by natural polymers. This might be due to solubilization effect of carrier that increased wetting property of drug. The data obtained from phase solubility study were depicted in table no. 5 .

Table 5: phase solubility data for Etoricoxib in carriers

\begin{tabular}{|l|l|l|l|}
\hline Conc. & Xanthan gum & Guar gum & $\begin{array}{l}\text { Gum } \\
\text { Acacia }\end{array}$ \\
\hline & \multicolumn{3}{|c|}{$\boldsymbol{\mu g} / \mathbf{m l}$} \\
\hline $\mathbf{0 . 2 5 \%}$ & 77.16 & 56.25 & 30.16 \\
\hline $\mathbf{0 . 5 0 \%}$ & 109.13 & 96.23 & 56.12 \\
\hline $\mathbf{1 \%}$ & 123.23 & 110.51 & 74.58 \\
\hline $\mathbf{2 \%}$ & 165.08 & 130.81 & 98.16 \\
\hline Pure drug & \multicolumn{3}{|c|}{$\mathbf{2 4 . 4 9} \boldsymbol{\mu g} / \mathbf{m l}$} \\
\hline
\end{tabular}




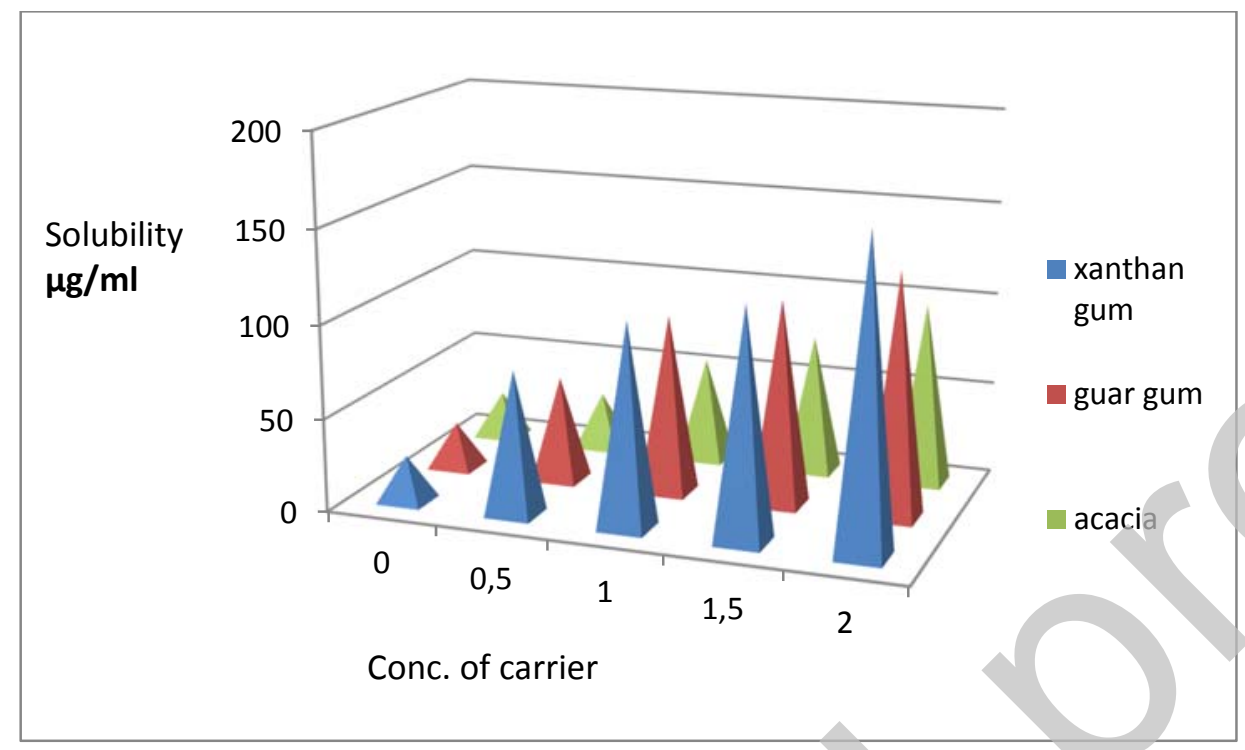

Figure 3: Phase solubility of etoricoxib with carrier

\section{Solubility study of solid dispersions and physical mixture}

Solubility data of pure etoricoxib were depicted in table 4 and indicated that $24.49 \mu \mathrm{g} / \mathrm{ml}$ of pure etoricoxib was soluble in distilled water; hence they are considered as poorly water soluble drugs. Here the solubility data of physical mixture containing etoricoxib and Xanthan gum, Guar gum and Gum Acacia is shown in table 6.

Table 6: Solubility of physical mixture of Etoricoxib and Xanthan gum, Guar gum and gum acacia

\begin{tabular}{|l|l|l|l|l|}
\hline $\begin{array}{r}\text { Formulation } \\
\text { code }\end{array}$ & $\begin{array}{l}\text { Distilled } \\
\text { Water } \\
(\mu \mathrm{g} / \mathrm{ml})\end{array}$ & $\begin{array}{l}\text { pH 1.2 } \\
(\mu \mathrm{g} / \mathrm{ml})\end{array}$ & $\begin{array}{l}\text { pH 6.8 } \\
(\mu \mathrm{g} / \mathrm{ml})\end{array}$ & $\begin{array}{l}\mathrm{pH} \mathrm{7.4} \\
(\boldsymbol{\mu g} / \mathrm{ml})\end{array}$ \\
\hline ETM1 & $25 \pm 0.66$ & $56 \pm 0.97$ & $84 \pm 0.66$ & $88 \pm 0.83$ \\
\hline ETM2 & $28 \pm 0.16$ & $64 \pm 0.24$ & $104 \pm 0.28$ & $125 \pm 0.45$ \\
\hline ETM3 & $37 \pm 0.41$ & $42 \pm 0.66$ & $90 \pm 0.68$ & $165 \pm 0.74$ \\
\hline ETM4 & $33 \pm 0.66$ & $59 \pm 0.88$ & $130 \pm 0.10$ & $146 \pm 0.23$ \\
\hline ETM5 & $42 \pm 0.61$ & $70 \pm 0.56$ & $82 \pm 0.96$ & $196 \pm 0.84$ \\
\hline ETM6 & $55 \pm 0.32$ & $96 \pm 0.45$ & $148 \pm 0.78$ & $220 \pm 0.26$ \\
\hline ETM7 & $98 \pm 0.84$ & $162 \pm 0.51$ & $182 \pm 0.24$ & $250 \pm 0.92$ \\
\hline
\end{tabular}




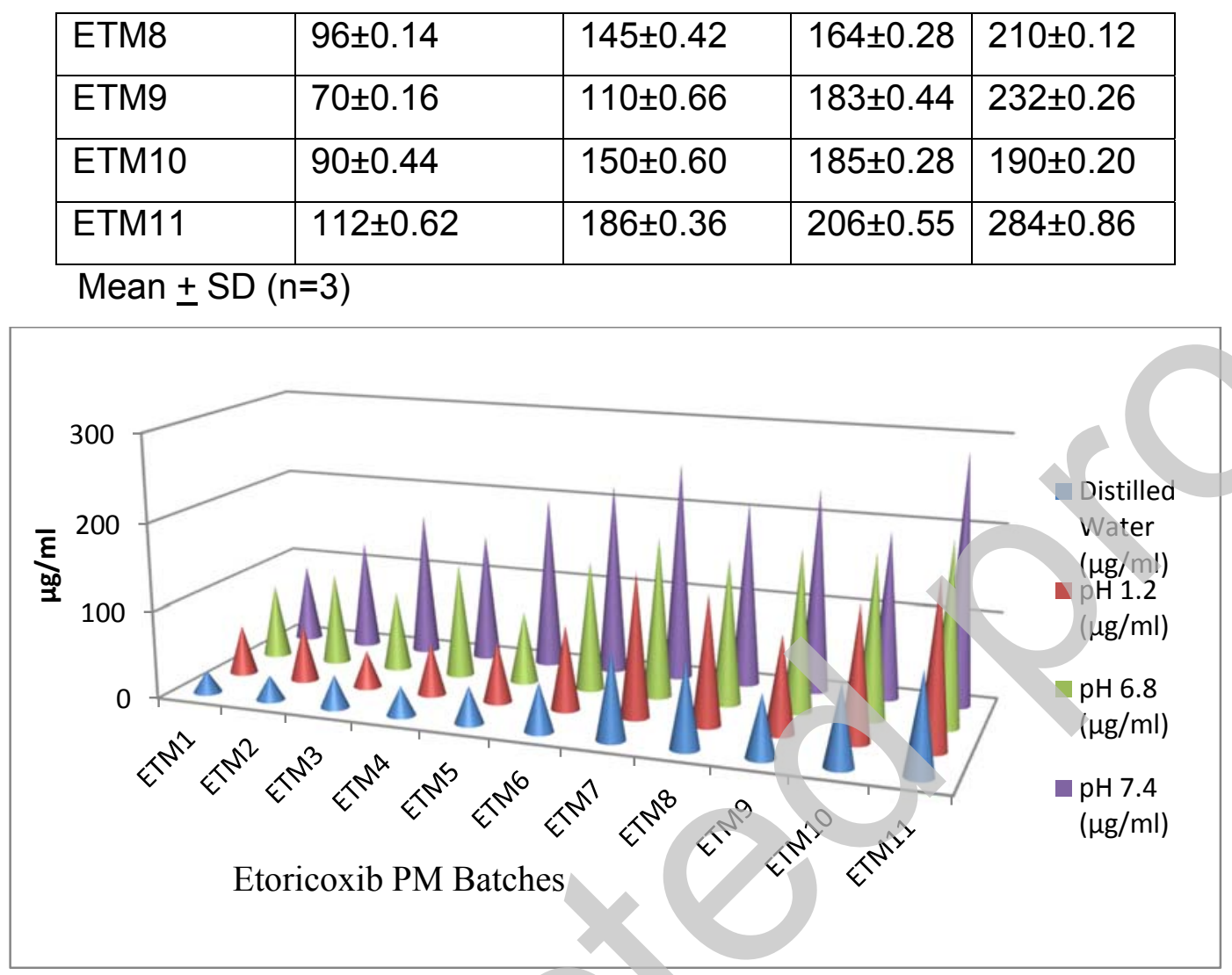

Figure 4: solubility profile of Etoricoxib physical mixture

The solubility of Etoricoxib in solid dispersion prepared by solvent evaporation method in different solvent also studied and the data for the same is depicted in table 7. As compare to pure and physical mixture, the solid dispersion prepared by solvent evaporation showed highest solubility in distilled water, $\mathrm{pH} 1.2$ acetate buffers, Phosphate buffer pH 6.8 and Phosphate buffer pH 7.4. (Figure 5)

This investigation suggested that, it might be possible due to preparation of solid dispersion using varying concentration of natural carrier which formed eutectic mixture and increased wettability of Etoricoxib, hence solubility.

Table 7: Solubility of Solid dispersion of Etoricoxib and Xanthan gum, Guar gum and gum acacia

\begin{tabular}{|c|c|c|c|c|}
\hline $\begin{array}{l}\text { Formulation } \\
\text { code }\end{array}$ & $\begin{array}{l}\text { Distilled Water } \\
(\mu \mathrm{g} / \mathrm{ml})\end{array}$ & $\begin{array}{l}\mathrm{pH} 1.2 \\
(\mu \mathrm{g} / \mathrm{ml})\end{array}$ & $\begin{array}{l}\mathrm{pH} 6.8 \\
(\mu \mathrm{g} / \mathrm{ml})\end{array}$ & $\begin{array}{l}\mathrm{pH} 7.4 \\
(\mu \mathrm{g} / \mathrm{ml})\end{array}$ \\
\hline
\end{tabular}




\begin{tabular}{|l|l|l|l|l|}
\hline ET1 & $50 \pm 0.86$ & $86 \pm 0.17$ & $104 \pm 0.66$ & $88 \pm 0.83$ \\
\hline ET2 & $89 \pm 0.66$ & $114 \pm 0.34$ & $120 \pm 0.28$ & $125 \pm 0.45$ \\
\hline ET3 & $70 \pm 0.48$ & $92 \pm 0.76$ & $132 \pm 0.68$ & $95 \pm 0.74$ \\
\hline ET4 & $120 \pm 0.16$ & $129 \pm 0.87$ & $160 \pm 0.10$ & $136 \pm 0.23$ \\
\hline ET5 & $60 \pm 0.68$ & $110 \pm 0.36$ & $112 \pm 0.96$ & $96 \pm 0.84$ \\
\hline ET6 & $96 \pm 0.22$ & $156 \pm 0.55$ & $188 \pm 0.78$ & $120 \pm 0.26$ \\
\hline ET7 & $160 \pm 0.44$ & $212 \pm 0.61$ & $252 \pm 0.24$ & $250 \pm 0.92$ \\
\hline ET8 & $96 \pm 0.14$ & $155 \pm 0.42$ & $264 \pm 0.28$ & $210 \pm 0.12$ \\
\hline ET9 & $170 \pm 0.17$ & $210 \pm 0.76$ & $233 \pm 0.44$ & $242 \pm 0.26$ \\
\hline ET10 & $99 \pm 0.74$ & $240 \pm 0.80$ & $285 \pm 0.28$ & $260 \pm 0.20$ \\
\hline ET11 & $192 \pm 0.92$ & $286 \pm 0.26$ & $306 \pm 0.55$ & $364 \pm 0.86$ \\
\hline
\end{tabular}

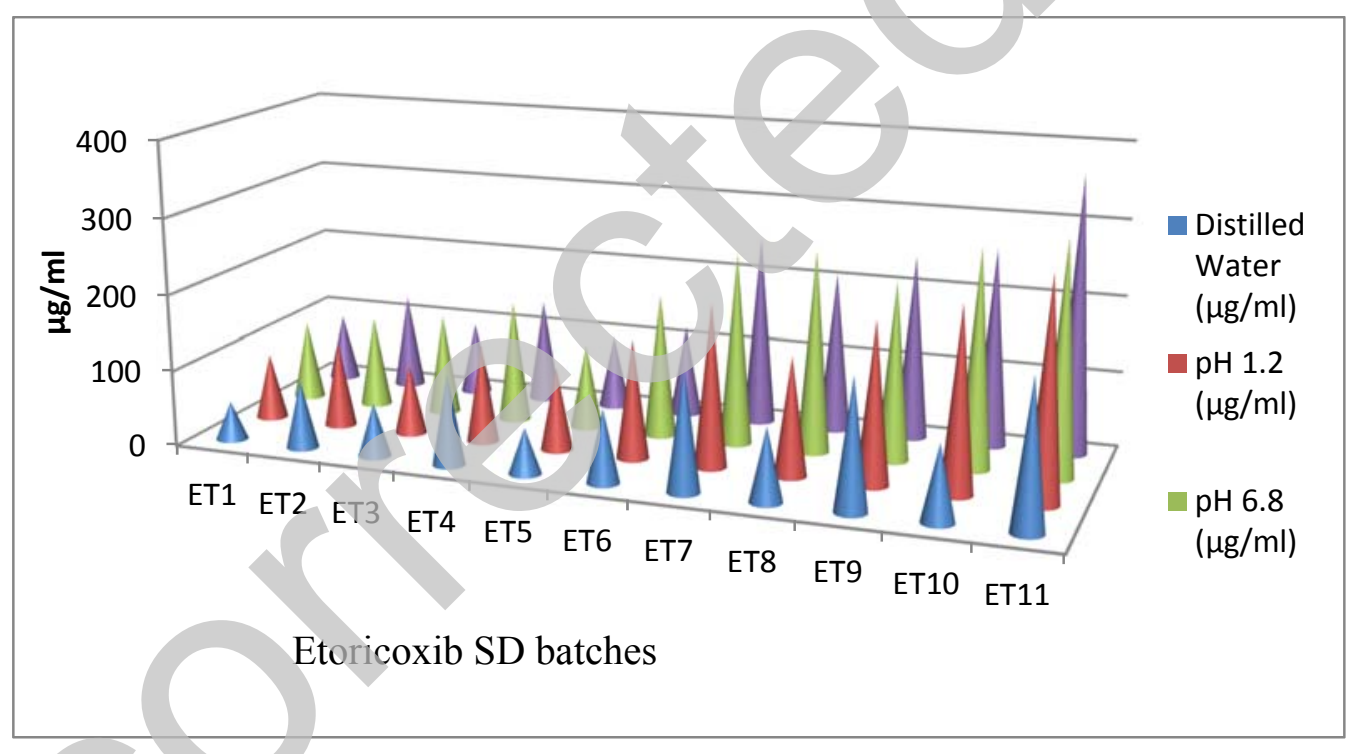

Figure 5: solubility profile of Etoricoxib Solid dispersion

\section{Percentage Yield of Solid dispersions}

Etoricoxib solid dispersion with Xanthan gum had a yield of 90.5 and $91.8 \%$ for the

Etoricoxib: Xanthan gum combination ratios of 1:1, and 1:2 (ET1 and ET2) respectively. The yield recorded for Etoricoxib: Guar gum solid dispersions at ratios of 1:1, and 1:2 were 94.2 and $96.4 \%$ (ET3 and ET4) respectively. Solid dispersion of Etoricoxib with Acacia at a ratio of $1: 1$ and $1: 2$ had yield of $93.0 \%$ and $98.12 \%$ (ET5 and ET6) 
respectively. Solid dispersion of Etoricoxib with Xanthan gum, Guar gum and gum acacia at a ratio of 1:1:1:1 had a yield of $97.10 \%$ (ET7). Solid dispersion of Etoricoxib with Xanthan gum, Guar gum and Acacia at a ratio of 1:2:1:1 had a yield of $98.2 \%$ (ET8). Solid dispersion of Etoricoxib with Xanthan gum, Guar gum and gum acacia at a ratio of 1:1:2:1 had a yield of $96.0 \%$ (ET9). Solid dispersion of Etoricoxib with Xanthan gum, Guar gum and gum acacia at a ratio of 1:1:1:2 had a yield of $94.0 \%$ (ET10) Solid dispersion of Etoricoxib with Xanthan gum, Guar gum and gum acacia at a ratio of 1:2:2:2 had a yield of $93.0 \%$ (ET11). (Figure 6)

Table 8: Percent yield of Etoricoxib solid dispersion

\begin{tabular}{|c|cc|}
\hline $\begin{array}{c}\text { Formulation } \\
\text { code }\end{array}$ & $\begin{array}{c}\text { Ratios } \\
\text { Etoricoxib: Xan } \begin{array}{c}\text { Acan gum: Guar gum: Gum } \\
\text { Acia }\end{array}\end{array}$ & \% yield \\
\hline ET1 & $1: 1: 0: 0$ & 90.5 \\
\hline ET2 & $1: 2: 0: 0$ & 91.8 \\
\hline ET3 & $1: 0: 1: 0$ & 94.2 \\
\hline ET4 & $1: 0: 2: 0$ & 96.4 \\
\hline ET5 & $1: 0: 0: 1$ & 93 \\
\hline ET6 & $1: 0: 0: 2$ & 98.12 \\
\hline ET7 & $1: 1: 1: 1$ & 97.1 \\
\hline ET8 & $1: 2: 1: 1$ & 98.2 \\
\hline ET9 & $1: 1: 2: 1$ & 96 \\
\hline ET10 & $1: 1: 1: 2$ & 94 \\
\hline
\end{tabular}




$$
\mid \begin{gathered}
\text { ET11 } \\
\text { Mean } \pm \text { SD }(n=3)
\end{gathered}
$$

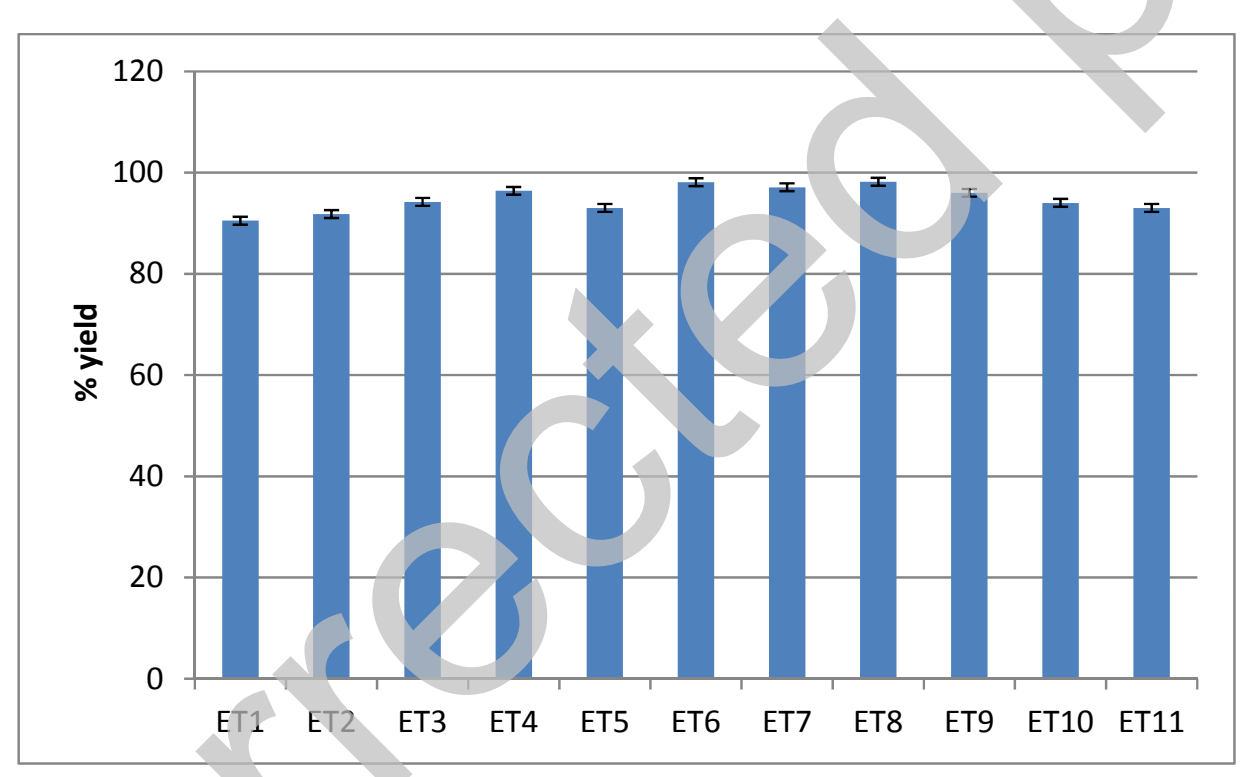

Figure 6: Effect of composition of polymers on yield of Etoricoxib solid dispersion

\section{Drug content of Solid dispersion and Physical mixture}

A fundamental quality attribute for all pharmaceutical preparations is the requirement for constant dose of drug between dispersion. In each of the mentioned formulae, no more than preparations outside this limit nor is one individual outside the limit. All the formulations and physical mixture contained active ingredients within the general limit of $90-110 \%$. Etoricoxib content (\%) with Xanthan gum, Guar gum and gum acacia in physical mixture and Solid dispersion with different drug: carrier ratio is shown in table 9 and 10 respectively. The entire percent drug shown in tables was found within general 
specification. It is proved that the formulation were prepared can be continue for further evaluation.

Table 9: Drug content of Etoricoxib solid dispersion

\begin{tabular}{|c|cc|}
\hline $\begin{array}{c}\text { Formulation } \\
\text { code }\end{array}$ & $\begin{array}{c}\text { Ratios } \\
\text { Etoricoxib: Xanthan gum: Guar } \\
\text { gum: Gum Acacia }\end{array}$ & $\begin{array}{c}\text { Drug } \\
\text { amount } \\
\mathbf{( \% )}\end{array}$ \\
\hline ET1 & $1: 1: 0: 0$ & 97.99 \\
\hline ET2 & $1: 2: 0: 0$ & 98.18 \\
\hline ET3 & $1: 0: 1: 0$ & 98.14 \\
\hline ET4 & $1: 0: 2: 0$ & 98.56 \\
\hline ET5 & $1: 0: 0: 1$ & 98.45 \\
\hline ET6 & $1: 0: 0: 2$ & 98.90 \\
\hline ET7 & $1: 1: 1: 1$ & 99.12 \\
\hline ET8 & $1: 2: 1: 1$ & 99.68 \\
\hline ET9 & $1: 1: 2: 1$ & 99.78 \\
\hline ET10 & $1: 1: 1: 2$ & 99.45 \\
\hline ET11 & $1: 2: 2: 2$ & 99.89 \\
\hline
\end{tabular}

Mean \pm SD $(n=3)$

Table 10: Drug content of Etoricoxib physical mixture

\begin{tabular}{|c|cc|}
\hline $\begin{array}{c}\text { Formulation } \\
\text { code }\end{array}$ & $\begin{array}{c}\text { Ratios } \\
\text { Etoricoxib: Xanthan gum: Guar } \\
\text { gum: Gum Acacia }\end{array}$ & $\begin{array}{c}\text { Drug } \\
\text { amount } \\
\mathbf{( \% )}\end{array}$ \\
\hline ETM1 & $1: 1: 0: 0$ & 98.01 \\
\hline ETM2 & $1: 2: 0: 0$ & 98.74 \\
\hline ETM3 & $1: 0: 1: 0$ & 98.57 \\
\hline ETM4 & $1: 0: 2: 0$ & 98.88 \\
\hline ETM5 & $1: 0: 0: 1$ & 98.71 \\
\hline ETM6 & $1: 0: 0: 2$ & 99.10 \\
\hline ETM7 & $1: 1: 1: 1$ & 99.12 \\
\hline ETM8 & $1: 2: 1: 1$ & 99.23 \\
\hline
\end{tabular}




\begin{tabular}{|c|cc|} 
ETM9 & $1: 1: 2: 1$ & 99.14 \\
\hline ETM10 & $1: 1: 1: 2$ & 99.38 \\
\hline ETM11 & $1: 2: 2: 2$ & 99.78 \\
\hline
\end{tabular}

Mean \pm SD $(n=3)$

\section{In-vitro dissolution study of SD's and PM's of Etoricoxib using natural carrier}

Dissolution studies were performed to compare the drug release from the physical mixtures and solid dispersions to that of the pure drug etoricoxib. The dissolution test was carried out for a period of $90 \mathrm{~min}$ in $\mathrm{pH} 6.8$ Phosphate buffer. The drug release data obtained for formulations ETM1-ETM11 are tabulated in Table 11. It shows the cumulative percent drug released as a function of time for all formulations. The cumulative percent drug released after 90 min was shown in table. In vitro studies reveal that there is marked increase in the dissolution rate of Etoricoxib from all the physical mixtures when compared to pure Etoricoxib itself. From the in- vitro drug release profile, it can be seen that formulation ETM11 containing Etoricoxib, Xanthan gum, Guar gum and gum acacia (1:2:2:2) shows higher dissolution rate i.e. 98.2ะ1.3\% compared with other formulations. It is predicted that, increasing concentration of carrier, increases the drug dissolution rate. The graphical presentation of dissolution profile of physical mixture of Etoricoxib, Xanthan gum, Guar gum and gum acacia over the period of $1.5 \mathrm{hrs}$ is shown in figure 7 .

Table 11: Drug released profile of PM's of etoricoxib using natural carrier

\begin{tabular}{|c|c|c|c|c|c|c|c|c|c|c|c|}
\hline \multirow{2}{*}{$\begin{array}{l}\text { Time } \\
\text { in } \\
\text { min. }\end{array}$} & \multirow[b]{2}{*}{ ETM1 } & \multirow[b]{2}{*}{ ETM2 } & \multicolumn{8}{|c|}{$\%$ drug release } & \multirow[b]{2}{*}{ ETM11 } \\
\hline & & & ETM3 & ETM4 & ETM5 & ETM6 & ETM7 & ETM8 & ETM9 & ETM10 & \\
\hline 0 & 0 & 0 & 0 & 0 & 0 & 0 & 0 & 0 & 0 & 0 & 0 \\
\hline 5 & $36.6 \pm 2$ & $39.3 \pm 2$ & $38.3 \pm 3$ & $43.4 \pm 2$ & $31.5 \pm 1$ & $38.2 \pm 2$ & $47.1 \pm 2$ & $48.1 \pm 1$ & $45.2 \pm 3$ & $46.6 \pm 2$ & $49.1 \pm 1$ \\
\hline 10 & $4 \overline{3.3} \pm 2$ & $46.9 \pm 1$ & $49.2 \pm 1$ & $52.8 \pm 2$ & $48.0 \pm 2$ & $46.8 \pm 3$ & $56.2 \pm 2$ & $55.6 \pm 2$ & $59.6 \pm 1$ & $58.7 \pm 3$ & $60.6 \pm 2$ \\
\hline 20 & $56.5 \pm 3$ & $58.5 \pm 2$ & $57.3 \pm 2$ & $61.5 \pm 1$ & $58.5 \pm 3$ & $59.2 \pm 2$ & $64.5 \pm 2$ & $62.8 \pm 2$ & $64.6 \pm 2$ & $68.8 \pm 2$ & $67.8 \pm 2$ \\
\hline 30 & $69.5 \pm 3$ & $71.2 \pm 2$ & $65.1 \pm 2$ & $70.8 \pm 1$ & $69.1 \pm 2$ & $71.4 \pm 2$ & $75.2 \pm 2$ & $78.2 \pm 2$ & $76.8 \pm 1$ & $73.4 \pm 1$ & $78.2 \pm 2$ \\
\hline 45 & $74.5 \pm 1$ & $76.5 \pm 2$ & $73.2 \pm 1$ & $75.5 \pm 1$ & $70.0 \pm 2$ & $76.2 \pm 2$ & $82.4 \pm 3$ & $85.6 \pm 3$ & $83.5 \pm 2$ & $80.7 \pm 3$ & $85.6 \pm 3$ \\
\hline
\end{tabular}




\begin{tabular}{|l|l|l|l|l|l|l|l|l|l|l|l|}
\hline 60 & $80.9 \pm 3$ & $87.3 \pm 2$ & $81.5 \pm 3$ & $89.9 \pm 1$ & $81.2 \pm 4$ & $85.2 \pm 2$ & $86.6 \pm 1$ & $88.2 \pm 2$ & $89.9 \pm 2$ & $84.4 \pm 2$ & $88.2 \pm 2$ \\
\hline 90 & $90.4 \pm 1$ & $90.5 \pm 2$ & $92.8 \pm 3$ & $91.2 \pm 1$ & $94.8 \pm 3$ & $95.2 \pm 2$ & $97.2 \pm 2$ & $97.8 \pm 2$ & $95.1 \pm 3$ & $96.6 \pm 1$ & $98.1 \pm 3$ \\
\hline
\end{tabular}

Mean \pm SD $(\mathrm{n}=3)$

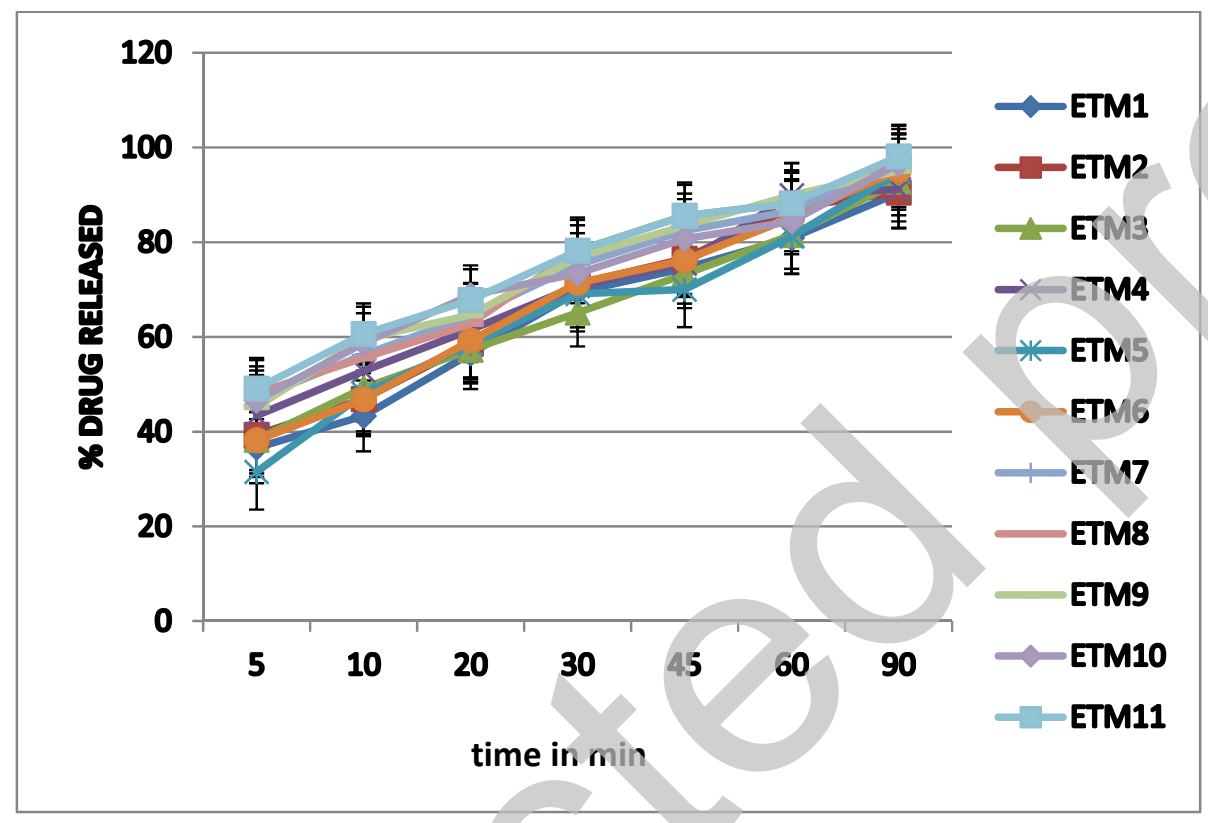

Figure 7: Drug release pattern of PM's of Etoricoxib using natural carrier

Percent drug released from solid dispersion of etoricoxib using natural carrier is shown in table 12. As compare to physical mixture of etoricoxib with natural carrier, solid dispersion showed highest dissolution rate for etoricoxib. Over the period of $90 \mathrm{~min}$, maximum $98 \%$ drug was released.

The percent diug released was increased with increasing concentration of carrier. The increase in dissolution of etoricoxib from the solid dispersions might be attributed to factors such as a reduction in the particle size of the drug in the matrix, increase in the surface area, reduced crystallinity, and an increase in the solubility of the drug in the presence of the lipid carriers.

The graphical presentation of drug released is shown in figure no. 8. The literature reveals that the solvent evaporation method of solid dispersion solubilizes the drug and carrier in molecular level. Hence form eutectic mixture and increased solubility of poorly water soluble drug. 
Table 12: Drug released profile of SD's of etoricoxib using natural carrier

\begin{tabular}{|c|c|c|c|c|c|c|c|c|c|c|c|}
\hline \multirow{2}{*}{$\begin{array}{l}\text { Time } \\
\text { in } \\
\text { min. }\end{array}$} & \multicolumn{11}{|c|}{$\%$ drug release } \\
\hline & ET1 & ET2 & ET3 & ET4 & ET5 & ET6 & ET7 & ET8 & ET9 & ET10 & ET11 \\
\hline 0 & 0 & 0 & 0 & 0 & 0 & 0 & 0 & 0 & 0 & 0 & 0 \\
\hline 5 & $26.6 \pm 2$ & $29.3 \pm 2$ & $28.3 \pm 3$ & $23.4 \pm 2$ & $21.5 \pm 1$ & $28.2 \pm 2$ & $27.1 \pm 2$ & $28.1 \pm 1$ & $25.2 \pm 3$ & $26.6 \pm 2$ & $29.1 \pm 1$ \\
\hline 10 & $33.3 \pm 2$ & $36.9 \pm 1$ & $39.2 \pm 1$ & $32.8 \pm 2$ & $38.0 \pm 2$ & $36.8 \pm 3$ & $46.2 \pm 2$ & $45.6 \pm 2$ & $49.6 \pm 1$ & $48.7 \pm 3$ & $50.6 \pm 2$ \\
\hline 20 & $46.5 \pm 3$ & $48.5 \pm 2$ & $47.3 \pm 2$ & $51.5 \pm 1$ & $48.5 \pm 3$ & $49.2 \pm 2$ & $54.5 \pm 2$ & $52.8 \pm 2$ & $54.6 \pm 2$ & $58.8 \pm 2$ & $57.8 \pm 2$ \\
\hline 30 & $59.5 \pm 3$ & $61.2 \pm 2$ & $60.1 \pm 2$ & $63.8 \pm 1$ & $65.1 \pm 2$ & $71.4 \pm 2$ & $75.2 \pm 2$ & $77.2 \pm 2$ & $76.8 \pm 1$ & $72.4 \pm 1$ & $78.2 \pm 2$ \\
\hline 45 & $74.5 \pm 1$ & $76.5 \pm 2$ & $78.2 \pm 1$ & $74.5 \pm 1$ & $72.0 \pm 2$ & $78.2 \pm 2$ & $80.4 \pm 3$ & $82.6 \pm 3$ & $84 . \overline{5 \pm 2}$ & $81.7 \pm 3$ & $87.6 \pm 3$ \\
\hline 60 & $84.9 \pm 3$ & $85.3 \pm 2$ & $80.5 \pm 3$ & $86.9 \pm 1$ & $81.2 \pm 4$ & $85.2 \pm 2$ & $89.6 \pm 1$ & $89.2 \pm 2$ & $89.9 \pm 2$ & $90.4 \pm 2$ & $91.2 \pm 2$ \\
\hline 90 & $90.4 \pm 1$ & $92.5 \pm 2$ & $91.8 \pm 3$ & $93.2 \pm 1$ & $93.8 \pm 3$ & $95.2 \pm 2$ & $\overline{97.2} \pm 2$ & $96.8 \pm 2$ & $95.1 \pm 3$ & $96.6 \pm 1$ & $98.1 \pm 3$ \\
\hline
\end{tabular}

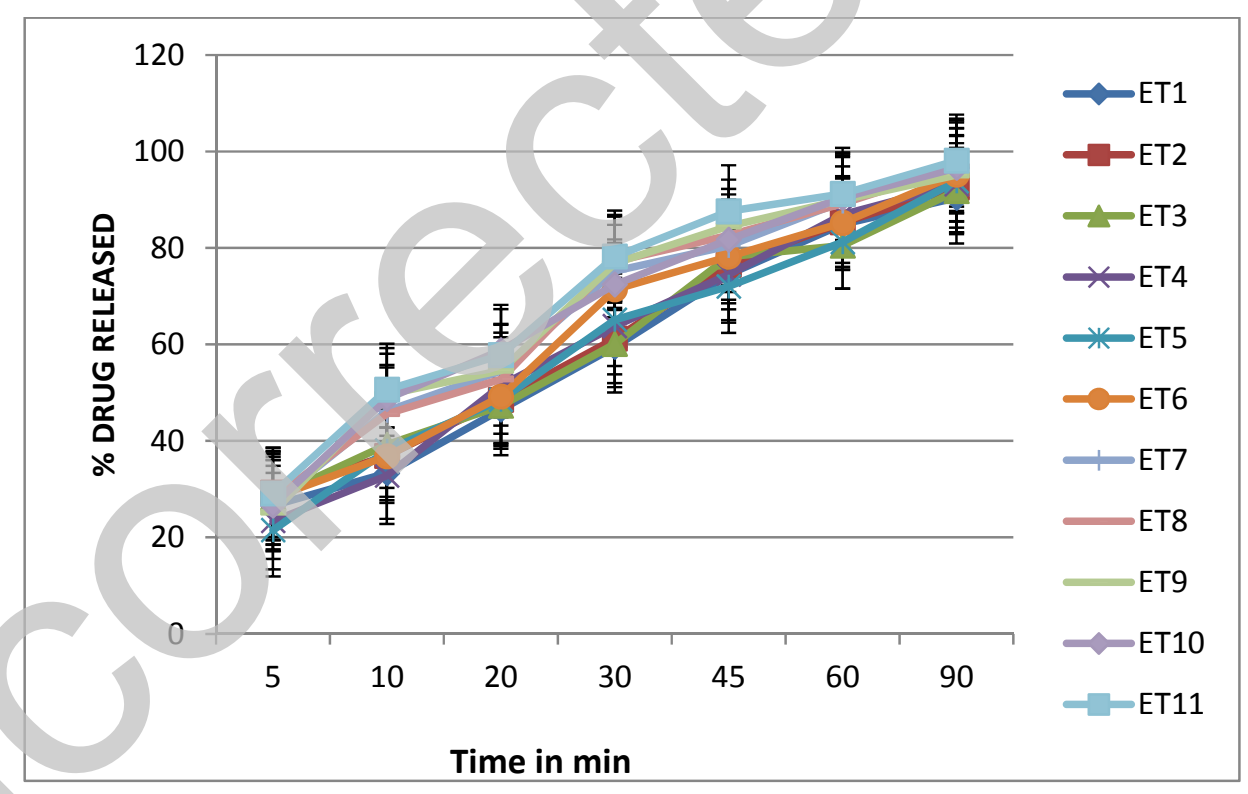

Figure 8: Drug release pattern of SD's of Etoricoxib using natural carrier 


\section{Fourier transforms infrared (FT-IR) spectral studies}

Infra-red spectrum of etoricoxib is shown in figure no. 9. The characteristic peaks of functional groups presents in the drugs were checked and depicted in table no.13. The functional groups present in the structure of etoricoxib were identified correctly and hence the drugs was confirmed and considered for further uses.

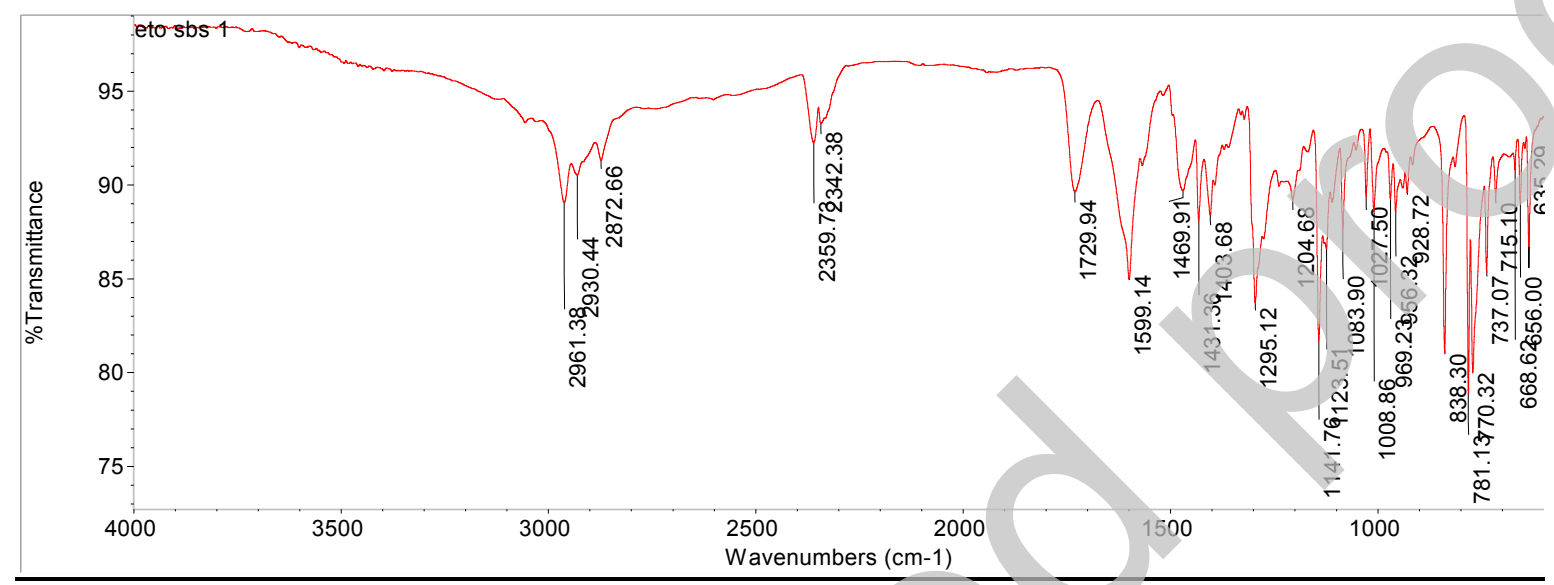

Figure 9: Infra-red spectrum of Etoricoxib

The IR spectra of pure Etoricoxib showed characteristic peaks at $1,596.9 \mathrm{~cm}^{-1}(\mathrm{C}=\mathrm{N}$ stretching vibration); $1,431 \mathrm{~cm}^{-1}, 1,300 \mathrm{~cm}^{-1}, 1,141.8 \mathrm{~cm}^{-1}$, and $1,085.8 \mathrm{~cm}^{-1}(\mathrm{~S}=0$ stretching vibrations); and $840.9 \mathrm{~cm}^{-1}, 775.3 \mathrm{~cm}^{-1}$, and $638 \mathrm{~cm}^{-1}$ (C-Cl stretching vibration), respectively (Figure 9).

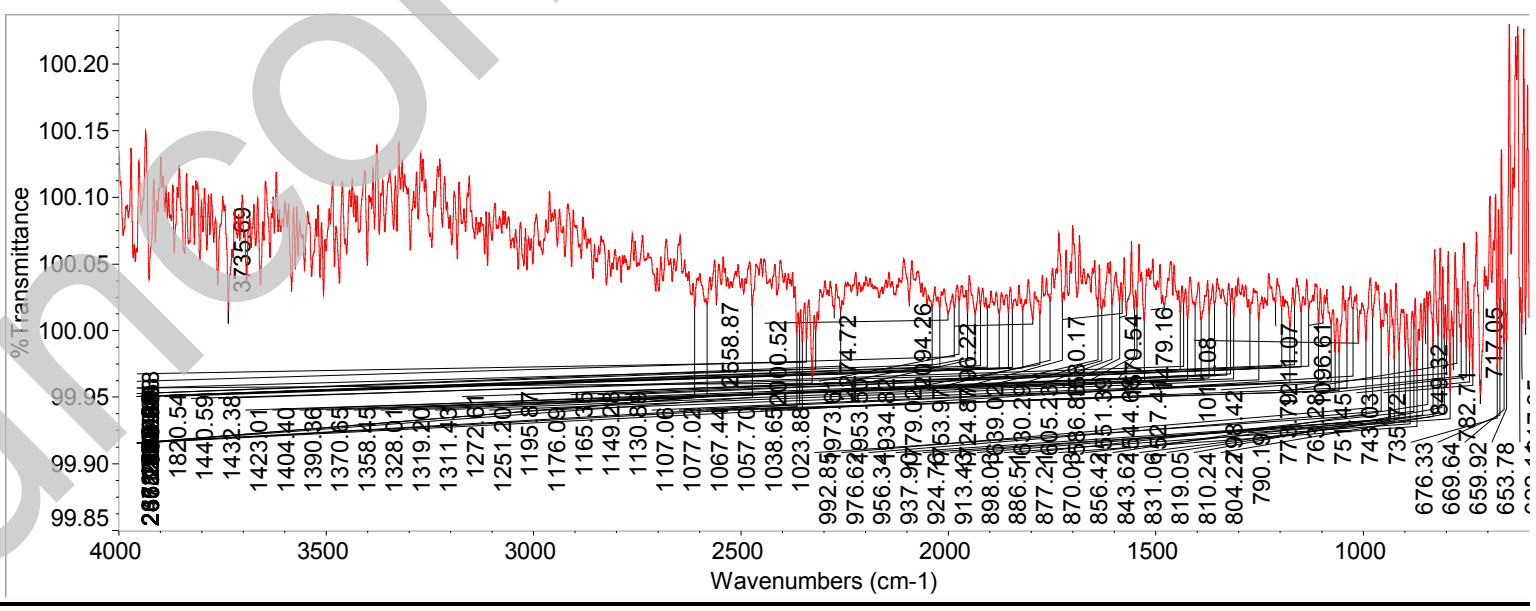


Figure 10: Infrared spectrum of Xanthan gum

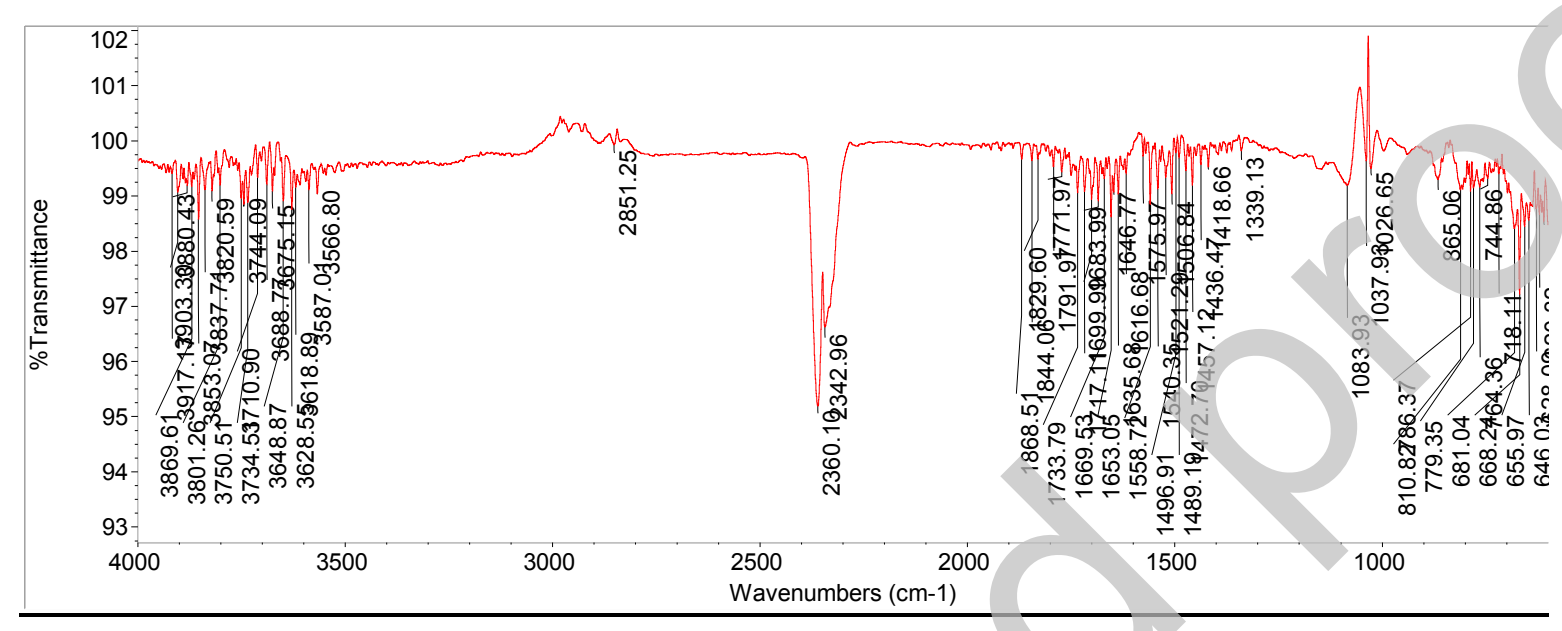

Figure 11: Infrared spectrum of guar gum

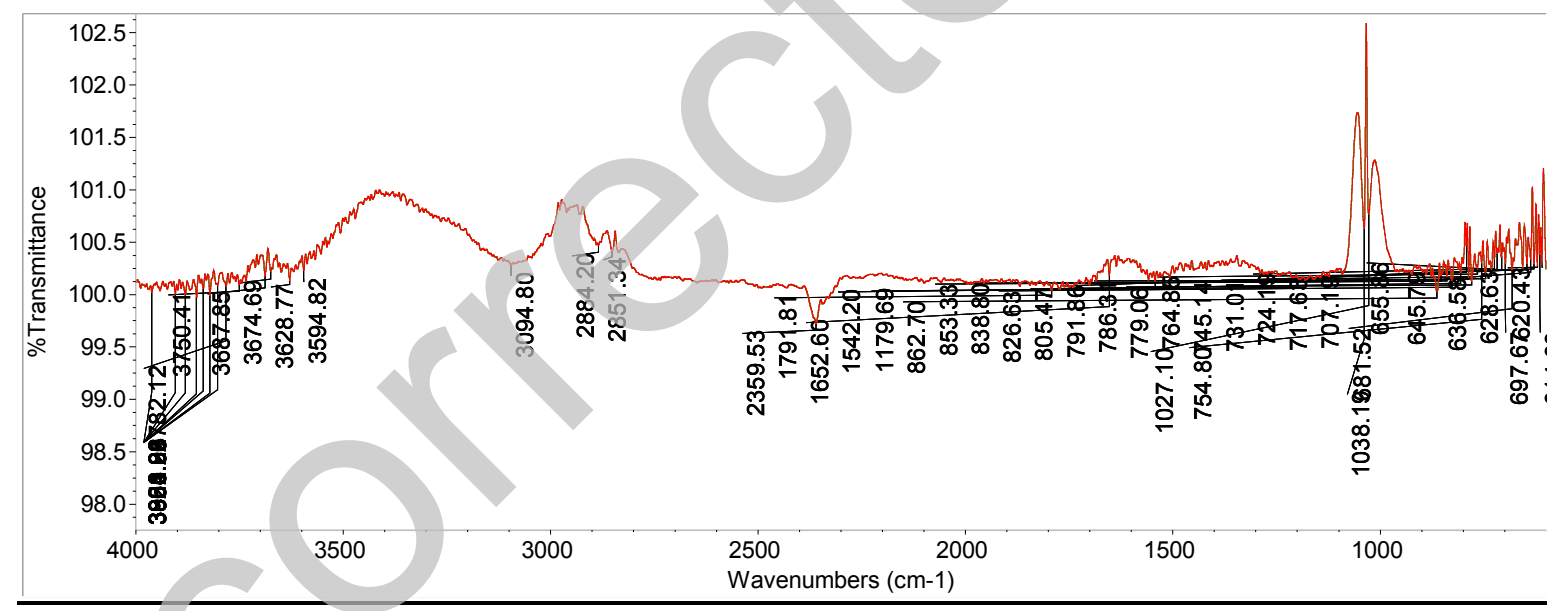

Figure 12: Infrared spectrum of gum acacia 


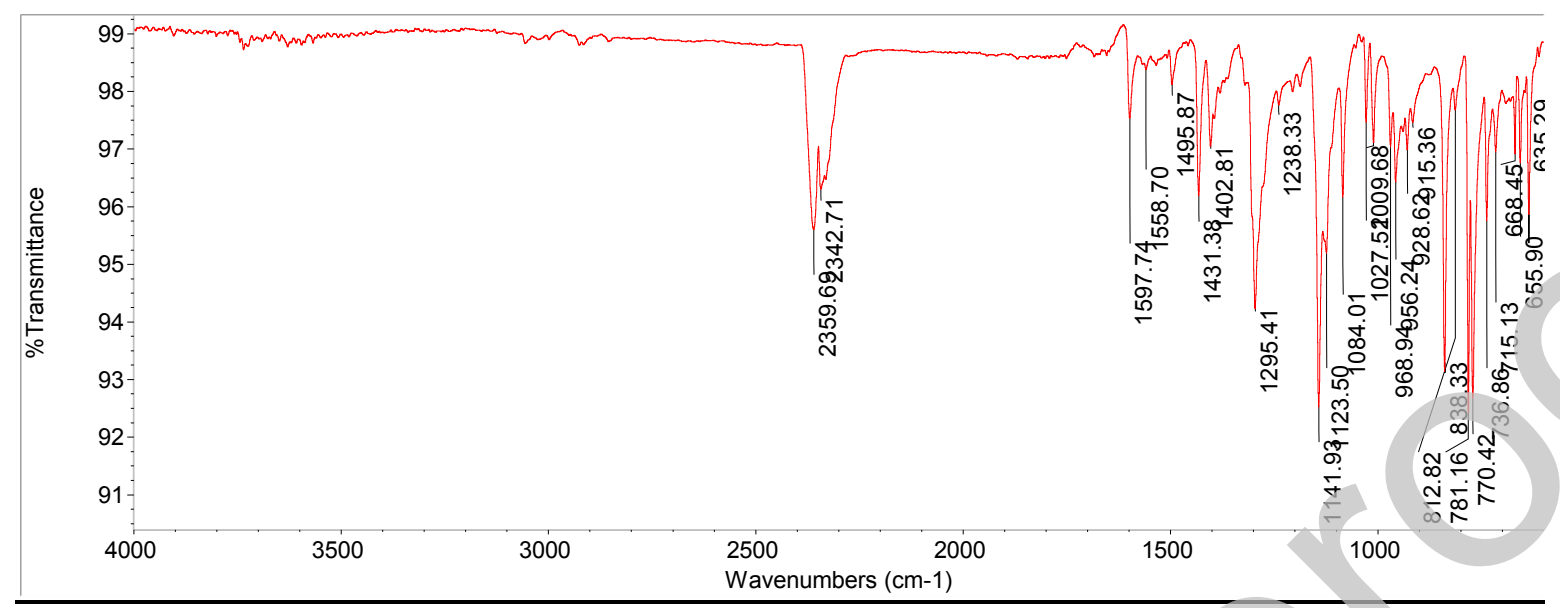

Figure 13: Infrared spectrum of etoricoxib and carrier mixture

From the spectrum it was observed that chemical groups $\mathrm{C}=\mathrm{N}$ stretching vibration, $\mathrm{S}=$ O stretching vibrations, C- I stretching vibration were found with the same wave number as that of etoricoxib (figure 13).

\section{DSC Studies}

DSC thermogram of Etoricoxib, Xanthan gum, Guar gum and gum acacia and its solid dispersion ET11 (1:2:2:2) shown in figure 14. The DSC thermogram of Etoricoxib pure drug was shown single sharp endothermic peak at $140.05^{\circ} \mathrm{C}$ indicating that the drug is highly crystalline. The DSC thermogram of solid dispersion of etoricoxib showed a shallow endotherm at $74.88^{\circ} \mathrm{C}$, indicating glass transition temperature, recrystallization peak at $112^{\circ} \mathrm{C}$ and a melting peak at $132^{\circ} \mathrm{C}$. This confirmed the transformation of crystalline etoricoxib into an amorphous etoricoxib hence improve dissolution. Physical mixture of Etoricoxib and Xanthan gum, Guar gum and Gum Acacia did not show such change figure 15. 


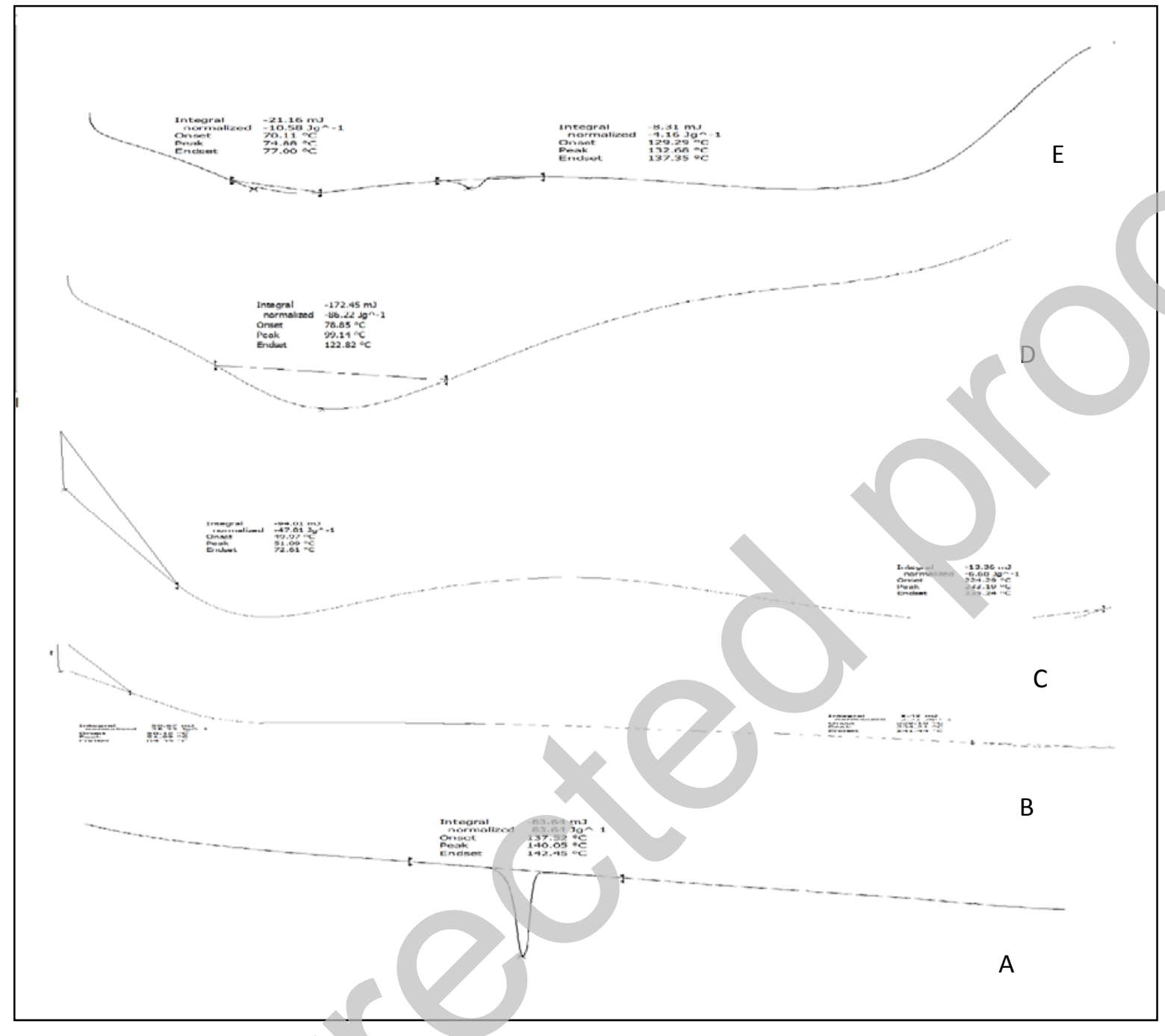

Figure 14: DSC thermogram of A- Etoricoxib, B- gum acacia, C-Guar gum, D- Xanthan gum and E- Etoricoxib and Xanthan gum, Guar gum and gum acacia solid dispersion

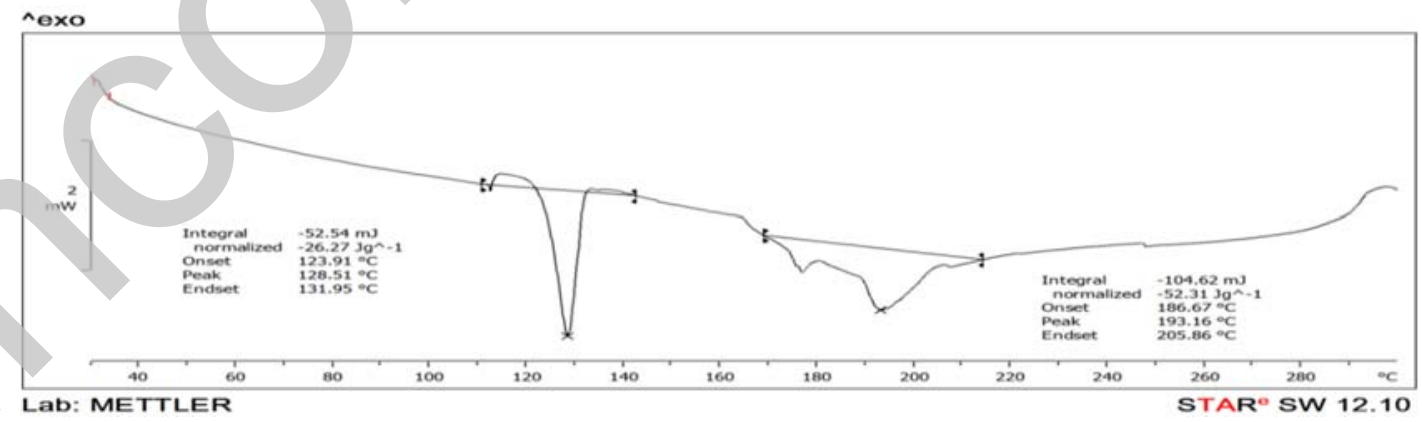

Figure 15: DSC thermogram of Etoricoxib and Xanthan gum, Guar gum and gum acacia physical mixture 


\section{Powder X-RD studies}

Powdered x-ray diffraction pattern of etoricoxib, Xanthan gum, Guar gum and gum acacia and solid dispersion ET11 is shown in figure 16. The XRPD patterns of pure etoricoxib showed numerous distinctive peaks in the region of 10 to $50^{\circ}\left(2\right.$ e) i.e. $17^{\circ}$, $18.2^{\circ}, 24.2^{\circ}, 29.2^{\circ}$ that indicated the crystalline nature of etoricoxib. The Powdered $x-$ ray diffraction study of etoricoxib solid dispersion (ET11) indicated a halo pattern seen in XRPD. It showed broad and diffuse maxima attributable to the relatively random arrangement of the constituent molecules, which produced poorly coherent scatters. These patterns were quite distinct from those produced by the crystalline etoricoxib. This confirmed the transformation of crystalline etoricoxib into an amorphous etoricoxib and was also supported by DSC results. The enhancement in the dissolution rate of the drug from the solid dispersion is ascribed to the marked reduction in the crystallinity of the drug.

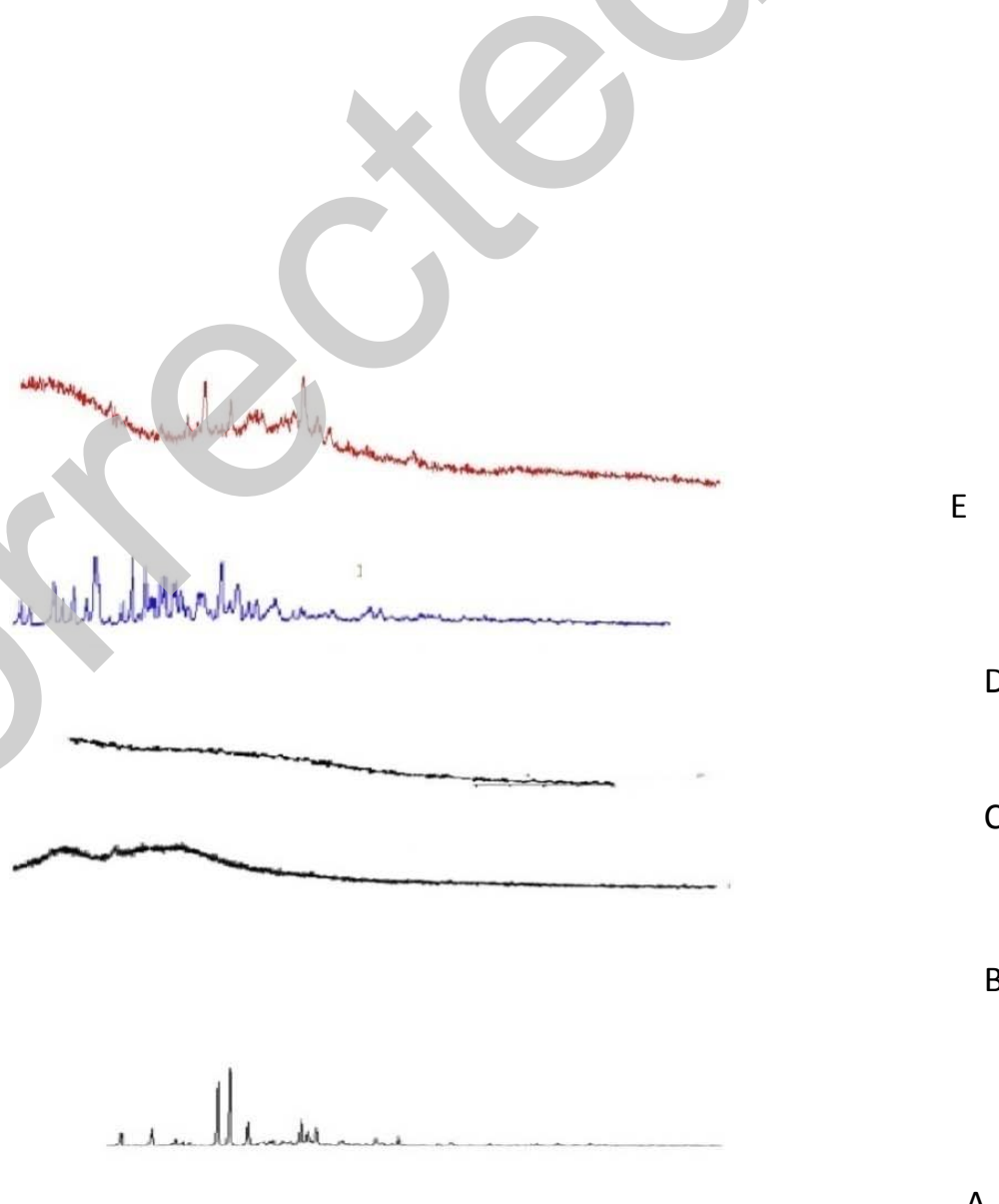


Figure 16: X-RD of A- etoricoxib, B- gum acacia, C-Guar gum, D- Xanthan gum and Eetoricoxib and Xanthan gum, Guar gum and gum acacia solid dispersion

\section{SEM studies}

SEM photographs for pure drug and optimized formulation ET11 are shown in figure 17 and 18 respectively. It was found that the presence of polymer in the solid dispersion influenced the particle size of the resultant agglomerates. The size of the particles increased with an increase in deposition of polymer on the surface of drug. The surface morphology studies revealed that the solid dispersion was closely compacted into small spherical form.

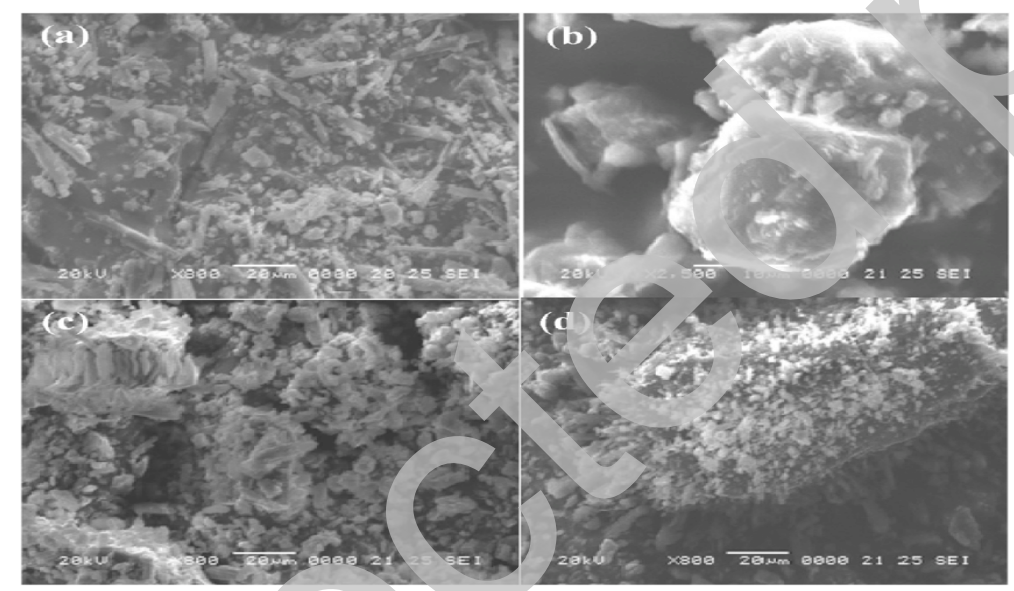

Figure 17: SEM of Etoricoxib 


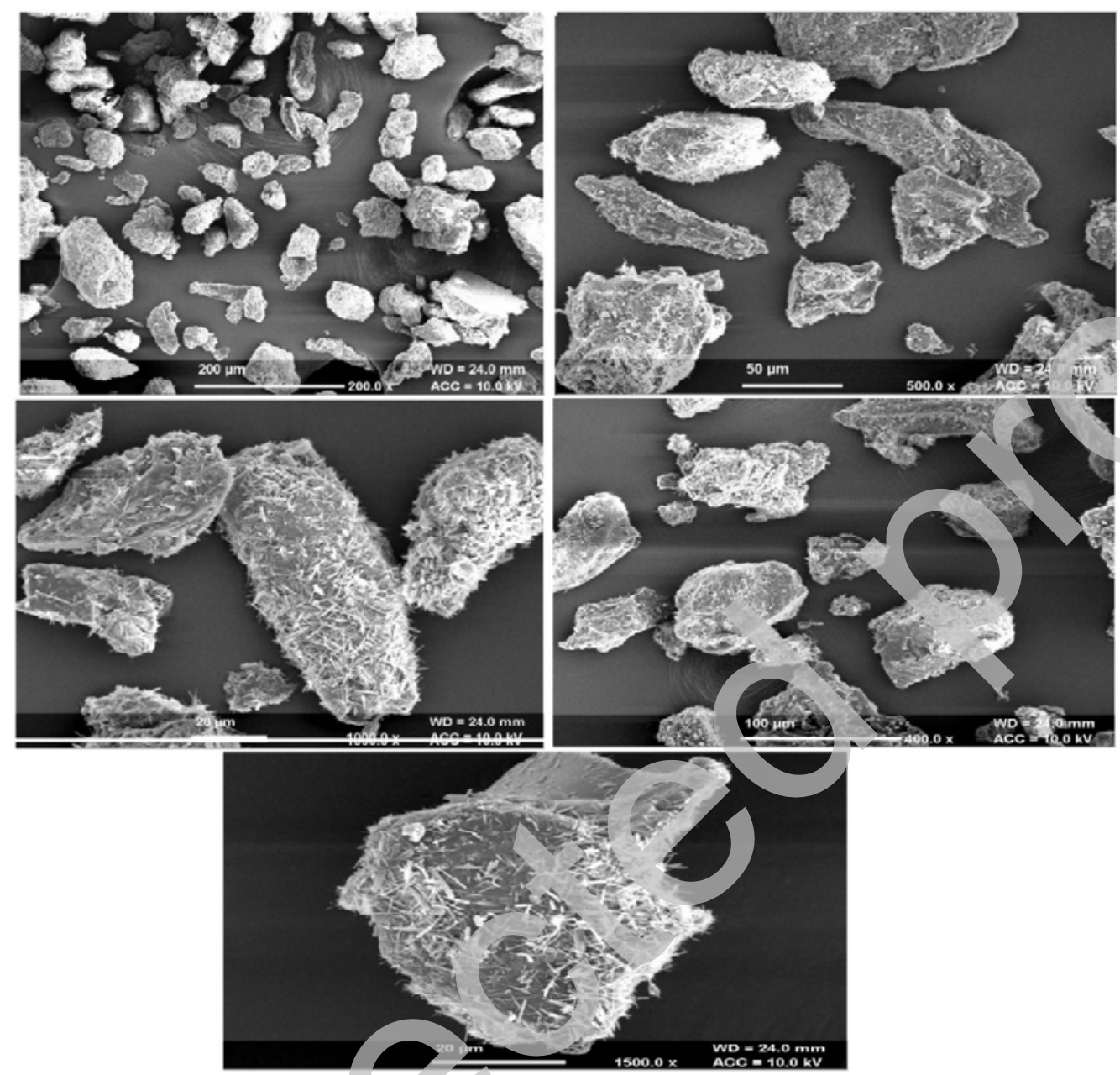

Figure 18: SEM study of Etoricoxib solid dispersion using natural carrier

\section{CONCLUSION:}

In the present study it was clearly demonstrated that etoricoxib solid dispersion formulation can be effectively produced by processing via solvent evaporation method with enhanced solubility and dissolution rate. Natural polymer combinations were optimized and stable SD systems were developed successfully. Utilization of Xanthan gum, Guar gum and gum acacia offers excellent possibilities to develop stable amorphous solid dispersion. Furthermore, this etoricoxib incorporated solid dispersion gave higher dissolution and solubility values compared to the pure etoricoxib drug. In vitro drug release studies of optimized formulation ET11 exhibited a cumulative release 
of $98.1 \pm 3 \%$ after $90 \mathrm{~min}$. FTIR spectrum revealed that no chemical interaction occurred between the drug and excipients used in the formulation. Analysis by differential scanning Calorimetry and powder X-ray diffraction showed that etoricoxib existed in the amorphous form within the solid dispersion formulation fabricated using the solvent evaporation process. Additionally, scanning electron microscopy studies suggested the conversion of crystalline etoricoxib to an amorphous form. The dissolution rate and solubility of etoricoxib solid dispersions was improved significantly using natural carriers' Xanthan gum, Guar gum and Gum Acacia.

\section{ACKNOWLEDGEMENTS}

The authors are grateful to Abbott Health Care Private Limited (India) for providing etoricoxib as a gift sample.

\section{REFERENCES}

1. Amidon $G L$, Lennernas $H$, Shah $V P$, Crison $J R, A$ theoretical basis for $a$ biopharmaceutical drug classification: Correlation of invitro drug product dissolution and in vivo bioavailability, Pharm. Res., 1995, 12, 413-420.

2. Shabnam Ain et al, An overview on various approaches used for solubilization of poorly soluble drugs, Pharm. Res., 2009, 2, 84-104.

3. Habib M J, Pharmaceutical solid dispersion technology, CRC, New York 2000.

4. Murali Mohan Babu GV, Prasad Ch D S, Raman Murthy K V, Evaluation of modified gum karaya as carrier for the dissolution enhancement of poorly water soluble drug nimodipine, Int J Pharm, 2002, 234,1-17.

5. Sapkal S, Narkhede M, Babhulkar M, Mehetre G, Rathi A, Natural polymers: Best carriers for improving bioavailability of poorly water soluble drugs in solid dispersion, Marmara Pharm J, 2013, 17, 65-72.

6. P Leclercq and M G Malaise, Etoricoxib (Arcoxia), Revue Medicale de Liege, 2004, vol. 59, pp. 345-349. 
7. M L Capone, S Tacconelli, and P Patrignani, Clinical pharmacology of etoricoxib, Expert Opinion on Drug Metabolism \& Toxicology, 2005, vol. 1, pp. 269-282.

8. D J Cochrane, B. Jarvis, and G. M. Keating, Etoricoxib Drugs, vol. 62, 2002, pp. 2637-2651.

9. D Patel and M Patel, Optimization of fast dissolving etoricoxib tablets prepared by sublimation technique, Indian Journal of Pharmaceutical Sciences, 2008, vol. 70,pp. 71-76.

10. H M Patel, B N Suhagia, S A Shah, I S Rathod and V K Parmar, Preparation and characterization of etoricoxib- $\beta$-cyclodextrin complexes prepared by the kneading method, Acta Pharmaceutica, 2007, vol. 57, pp. 351-359.

11.Gopal Venkatesh Shavi, Usha Yogendra Nayak, Ramesh Raghavendra, Shrawan B and Meka Sreenivasa Reddy. Enhanced Dissolution and Bioavailability of Etoricoxib in Solid Dispersion Systems: An Investigation into the Role of Carrier Matrix on Stability, In vitro and in vivo Performance. RRJPPS. 2016; 5(1): 55-63.

12. Higuchi T, Connors KA, Phase solubility techniques. Adv Anal Chem Instrum 1965, 4, 117.

13. Monica R, Yogesh M, Kaushik T Suheta B, Dissolution improvement of simvastatin by surface solid dispersion technology, Dissolution Technologies 2010, 27-34.

14. Ketkar AR, Patir VB, Paradkar AR, Computer aided exploratory data analysis model fitting for dissolution kinetics, Fourth International Symposium on Advances in Technology and Business Potential of New Drug Delivery System. Mumbai, India, Controlled Release Society Indian Chapter, 2002; 62. 